\title{
الاحتياجات التدريبية لمعلمات صعوبات التعلم وعلاقتها ببعض \\ المتغيرات الديموغرافية بمحافظة وادي الدواسر
}

The training needs for learning disabilities teachers and its relationship to some demographic variables in Wadi Al-Dawasir

Governorate

\author{
sldel \\ ا. أه/هنادي عيشى مهنا إبراهيم \\ جامعة سطام بن عبد العزيز

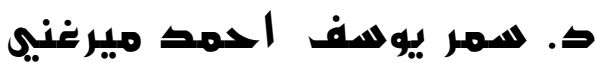 \\ جامعتي الاميرسطام بن عبد العزيزوالامام المهدي \\ Doi: 10.21608/jasht.2021.161836

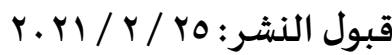

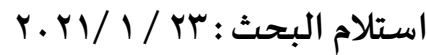

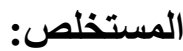

هدف البحث الحالي الى تحديد الاحتياجات التدريبية لمعلمات صعوبات التعلم

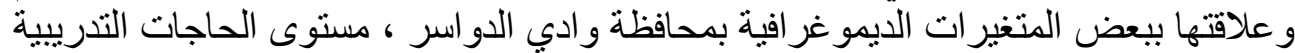

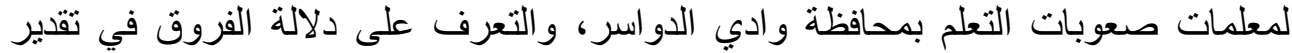

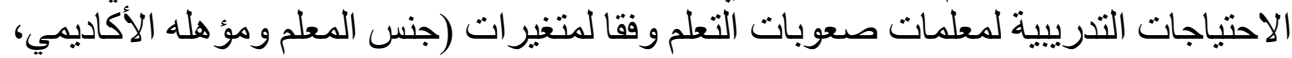

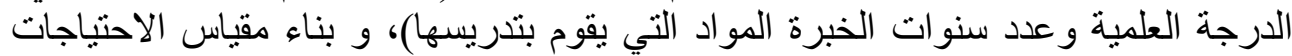

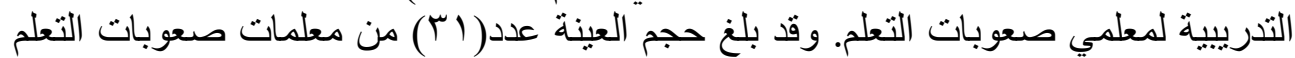

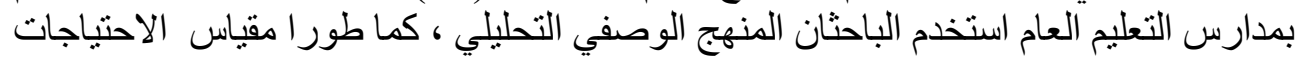

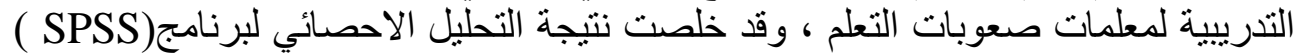

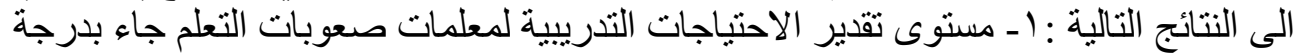

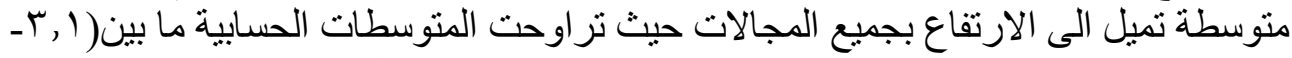

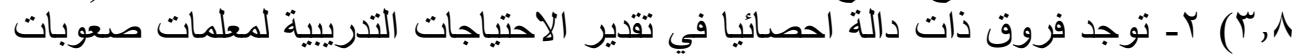

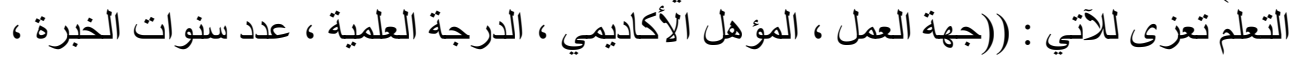

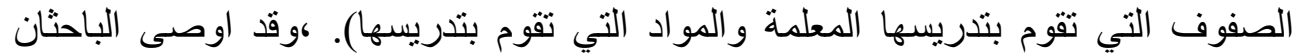
بضرورة تقديم بر امج تدريب نو عية عالية الجودة لمعلمات صعوبات المعات التعلم. 
الكلمات المفتاحية :الاحتياجات التدريبية_معلمات صعوبات التعلم، التربية الخاصة.

Abstract:

The aim of the current research is to determine the training needs for teachers of learning disabilities and their relationship to some demographic variables in Wadi Al-Dawasir Governorate. The sample size reached (31) of learning difficulties teachers in general education schools. The result of a statistical analysis of the SPSS program concluded the following results: 1- The level of training needs assessment for learning difficulties teachers came with an average degree tending to rise in all fields where the arithmetic averages ranged between (3.1-3.8) 2- There are statistically significant differences in estimating the training needs for difficulties teachers The learning is attributed to the following: ((The employer, the academic qualification, the academic degree, the number of years of experience, the classes taught by the teacher and the materials that he teaches).

Key words: Training needs, Teachers disabilities

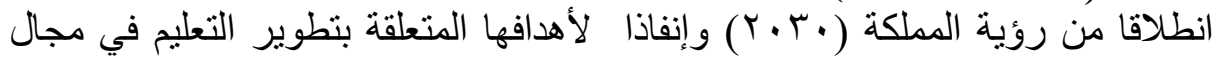
مقدمة البحث (Introduction):

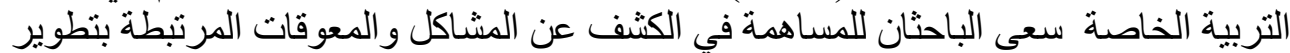

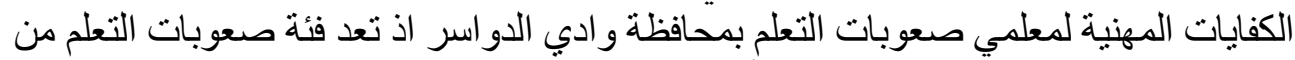

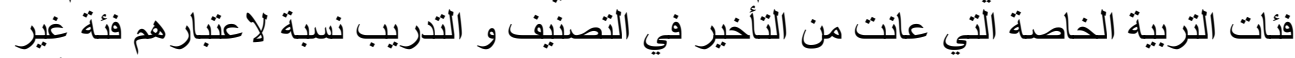

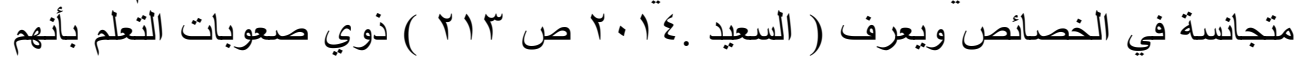

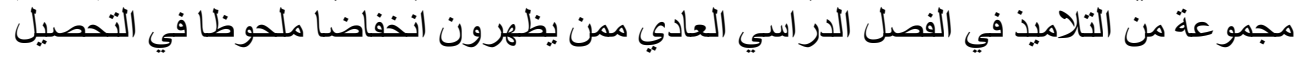

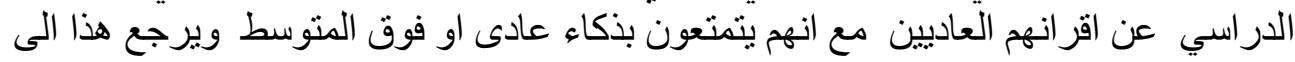

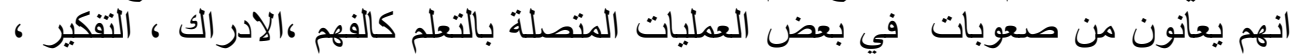

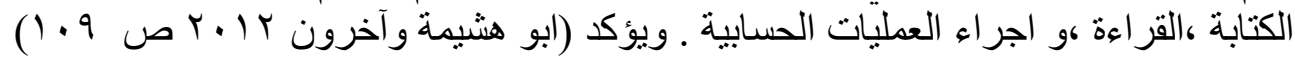

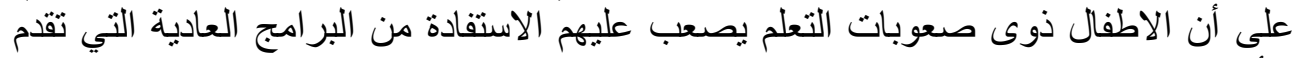

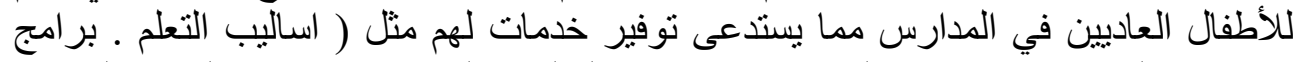

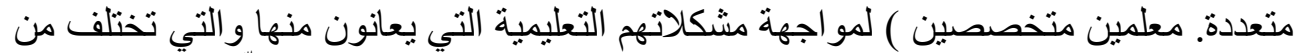

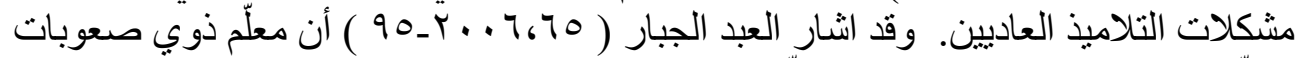

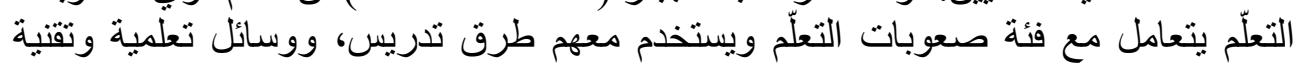


خاصة، ويُعدّ لهم برامج تربوية تتتاسب واحتباجاتهم وقداراتهم، لذا ينبغي الاهتمام بتطوير

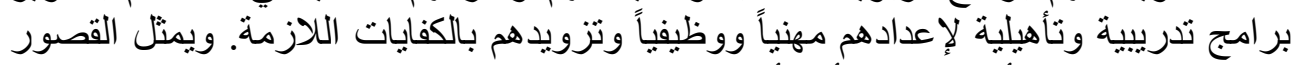

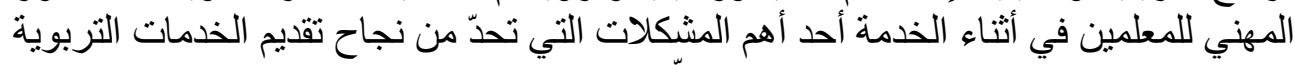

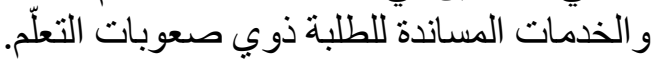
-

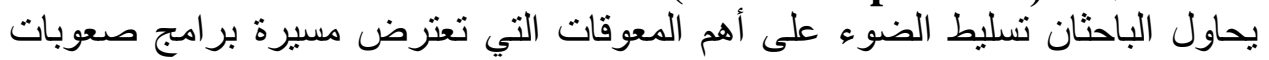

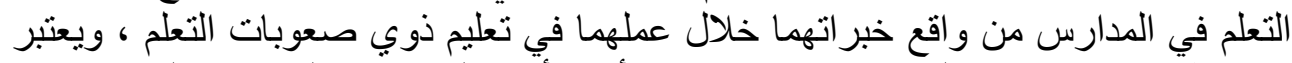

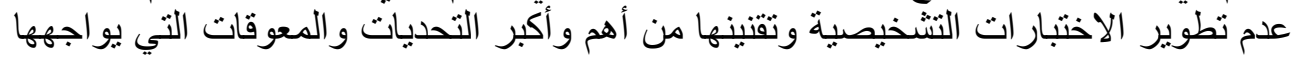

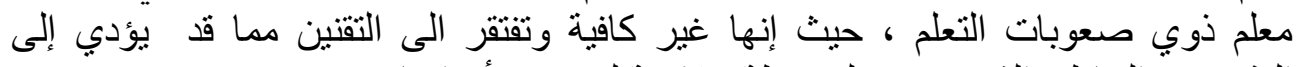

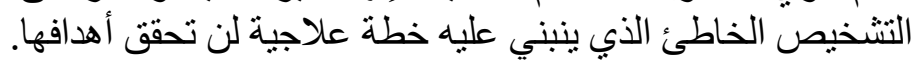

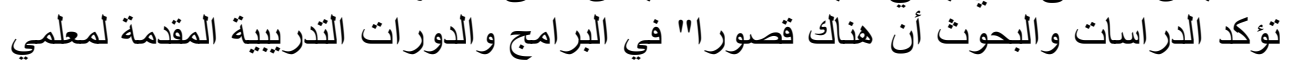

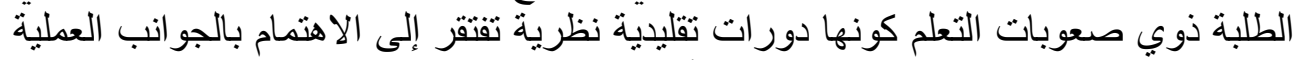

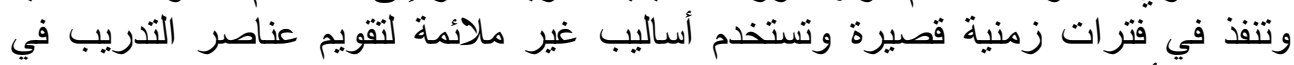

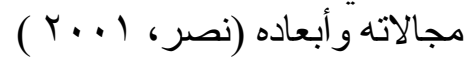

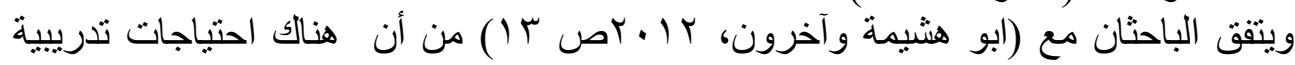

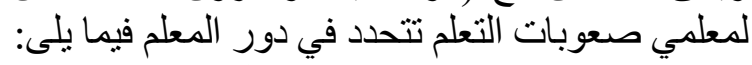

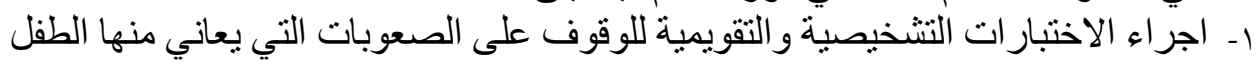

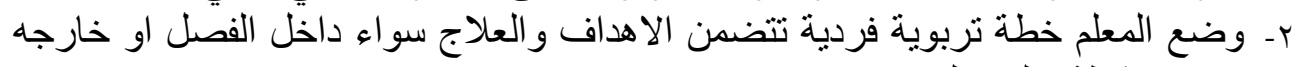

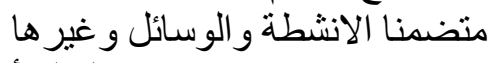
rـــ استخدام غرفة مصادر التعلم أو اى غرفة بالى بالمدرسة لتقديم العون للطفل سواء فردى أو

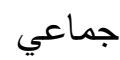
ع- وضع برامج تربوية للأطفال الذين يعانون من صعو بات تعليمية

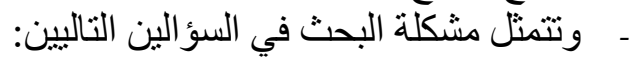

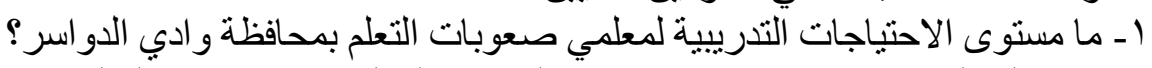

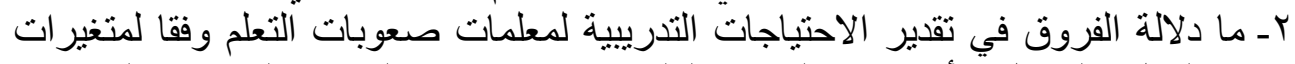

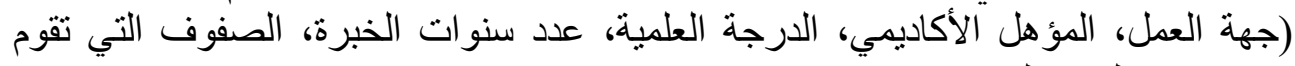
بتدريسها، و المو اد التي تنوم بتدريسها). أهداف البحث (Objectives):

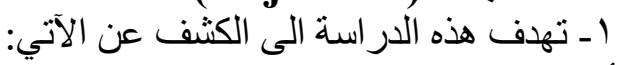
أــ مستوى الحاجات التدريبية لمعلمات صعوبات التعلم بمحافظة وادي الدو اسر. 
ب-دلالة الفروق في تقدير الاحنياجات التدرييية لمعلمات صعوبات التعلم وفقا لمتغيرات

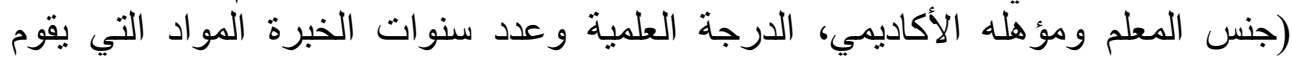
بتدريسها). r - بناء مقياس الاحتياجات التدريبية لمعلمي صعوبات التعلم. - - أهمية البحث( Research necessity) -

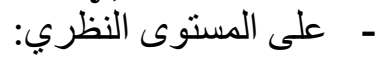

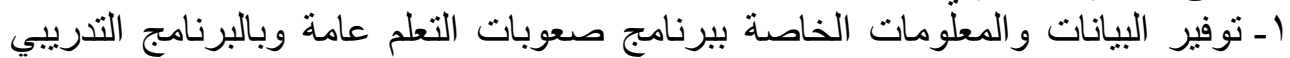

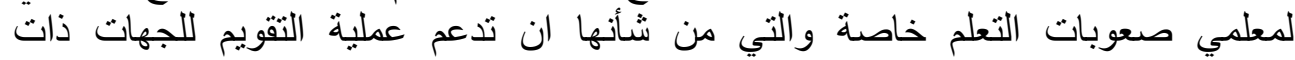
الاختصاص بمحافظة و ادي الدو اسر.

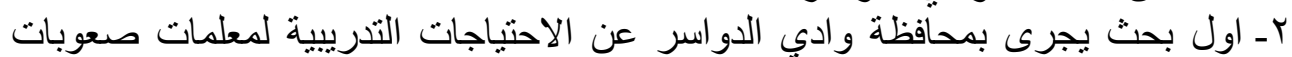
التعلم حسب علم الباحثين. rـ الخروج بتوصيات قد يعمل تطبيقها على سد الفجوة بين الواقع و المأمول وتصحيح مسار

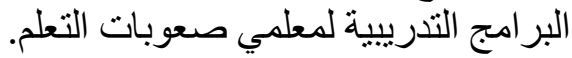

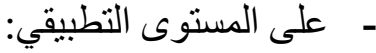
اـ مساعدة القائمين على تخطيط النطين وبناء وتطوير البرامج التدريبية لمعلمي صعوبات التعلم

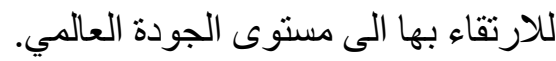
r- مساعدة القائمين على تطوير برامج الئ تقويم الأداء لمعلمي صعوبات التعلم بمحافظة وادي الدو اسر - النروض البحث (Research hypotheses): 1 - يتسم تقدير مستوى الحاجات التدريبية لمعلمات صعوبات التعلم بمحافظة وادي الدواسر

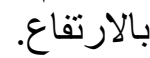

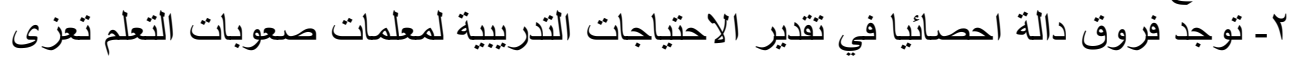

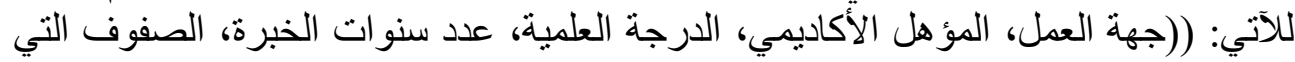

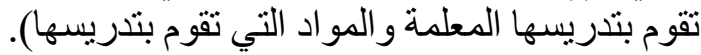
- حدود البحث (Research limits):

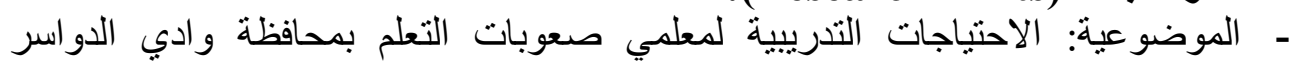
و علاقتها ببعض المتوعنة الاحتير ات الديمو غر افية.

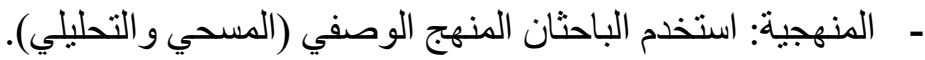

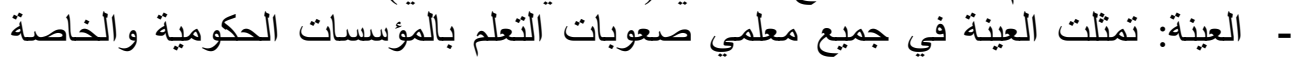
بمحافظة وادي الدواسر وقد تم اختيار العينة قصديا.

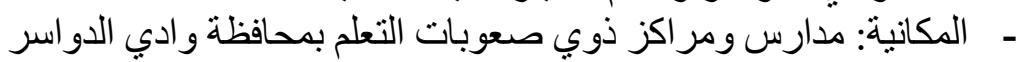

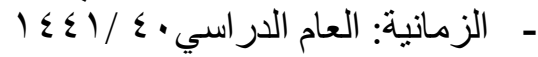




\section{- مفاهيم البحث(Terminology):} 1 الاحتياجات التدريبية:

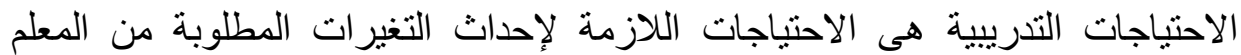

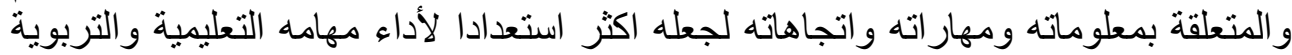

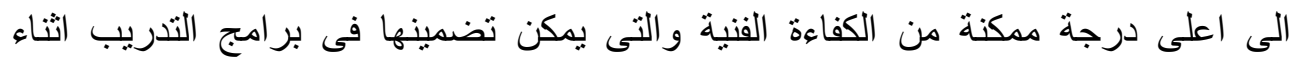

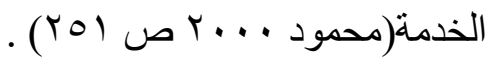

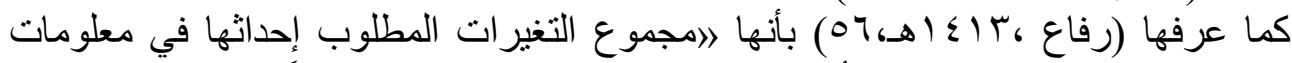

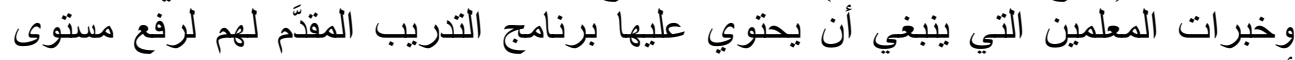
أدائهمبن. r - صعوبات التعلم:

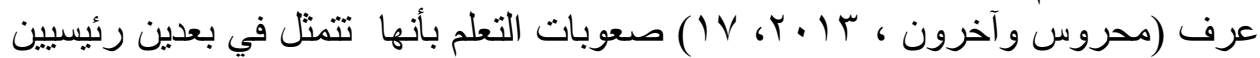

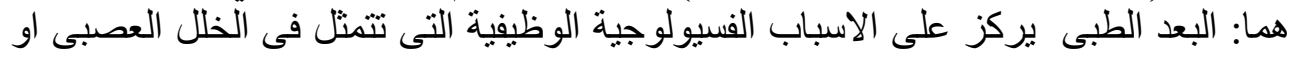

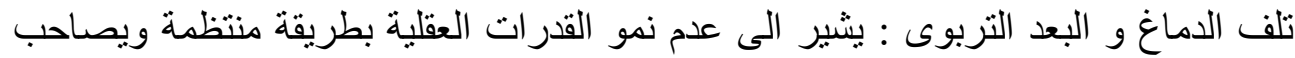

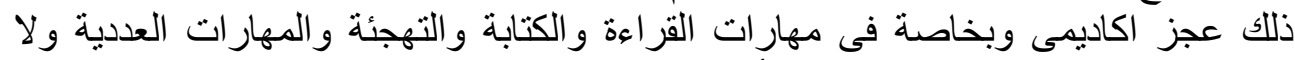

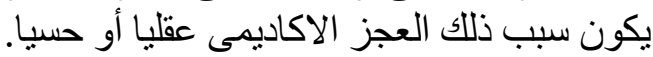

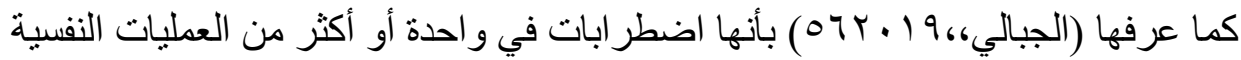

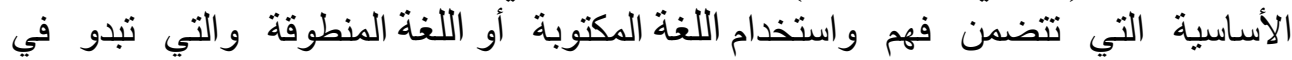

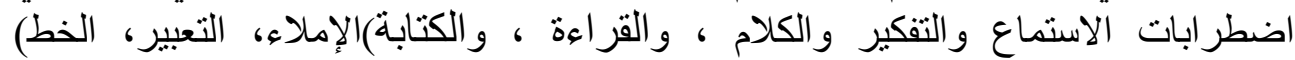

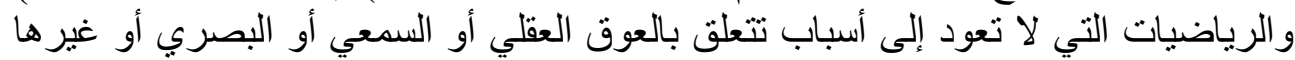

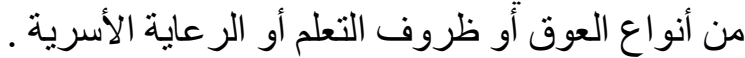

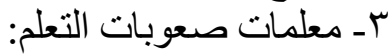

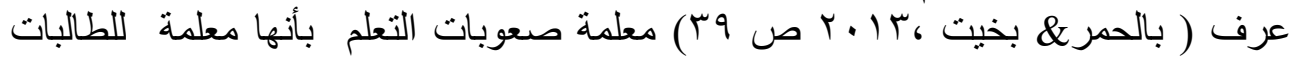

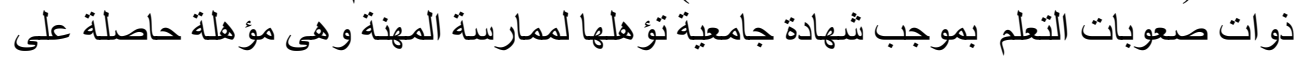

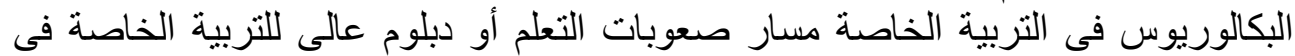

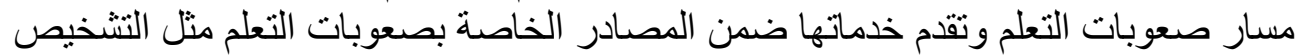

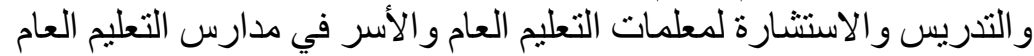

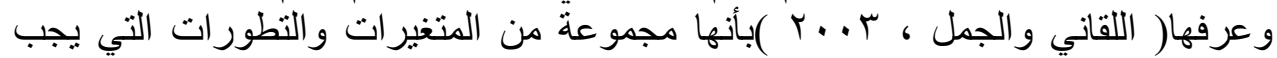

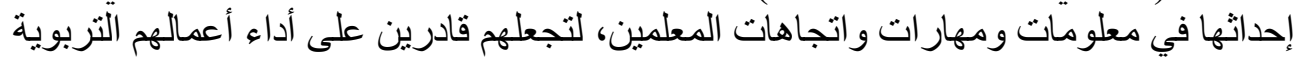

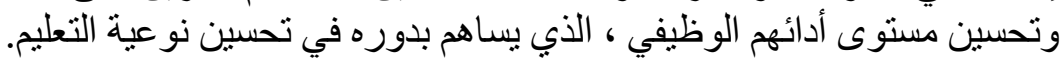
- مو وادي الدو اسر: هي إحدى محافظات منطقة الرياض في المملكة العربية السعودية ويبلغ عدد سكانها

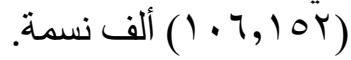


- الإطار النظري (Theoretical framework):

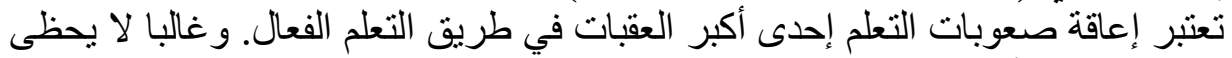

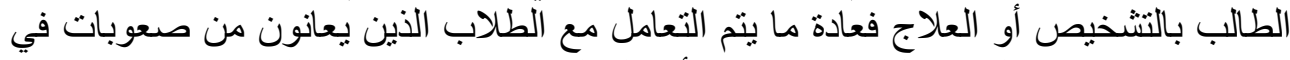

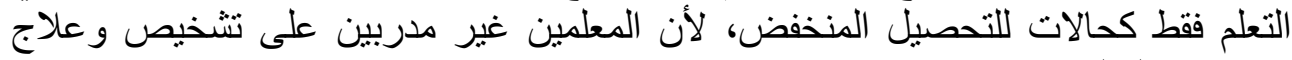
صعوبات التعلم. (Soy,2015,201)

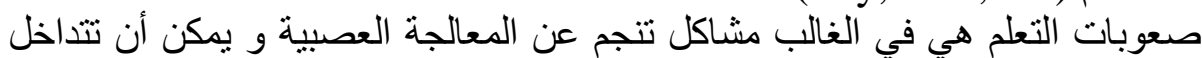

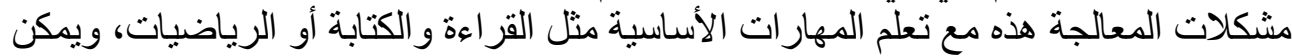

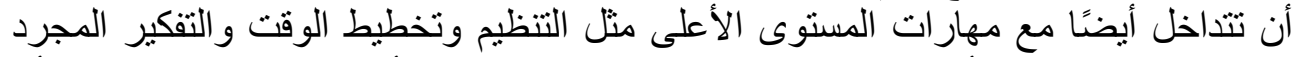

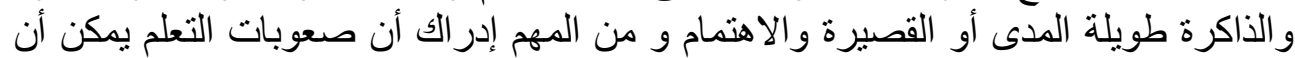

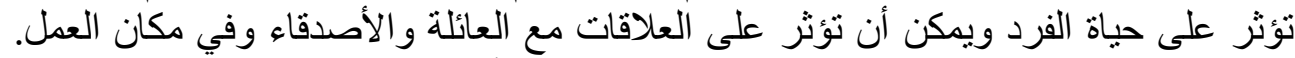

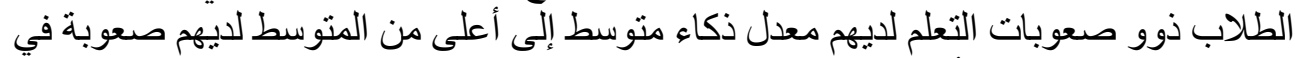

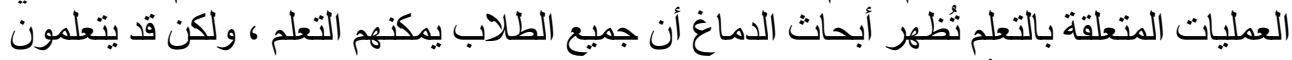

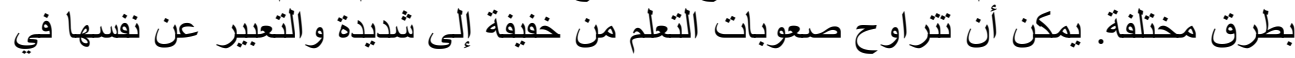

صور متتو عة. ( Learning Disabilities Association of America, 2019,2) من الضروري خلق وعي عام بعلامات التدخل المبكر. وتقديم خدمات التعلم الخاص فور

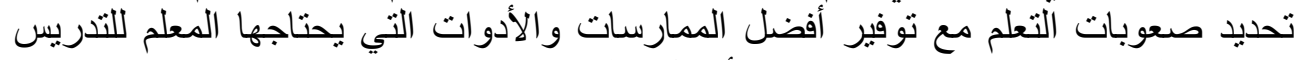

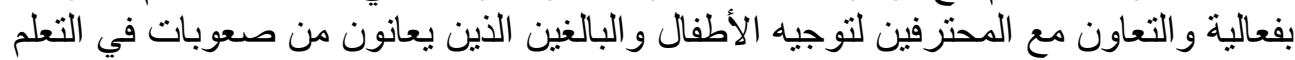

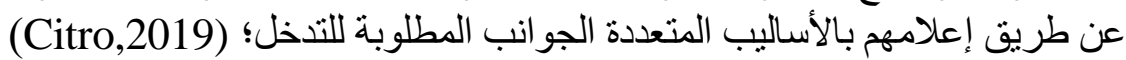

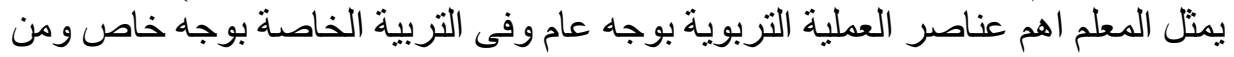

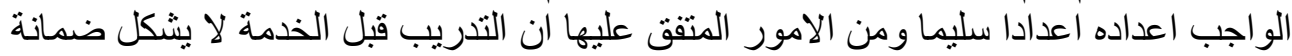

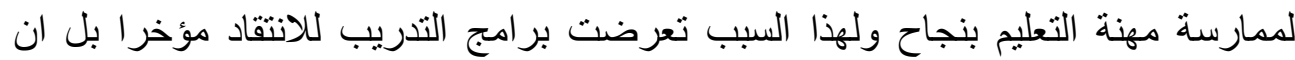

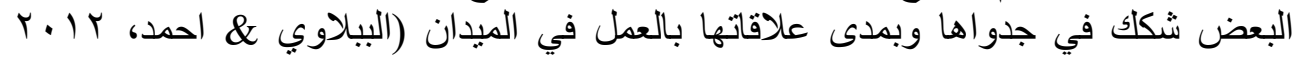

ونتيجة للاهتمام العالمي بفئات الطلبة ذوي الاحتياجات الخاصة، ظهرت إعاد اتجاهات حديثة

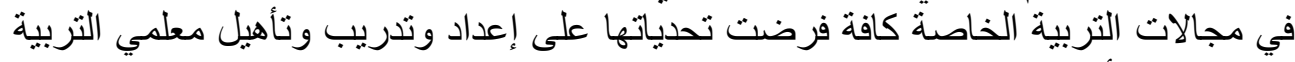

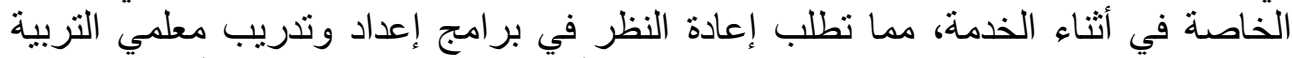

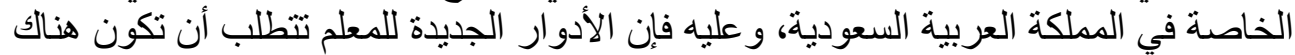

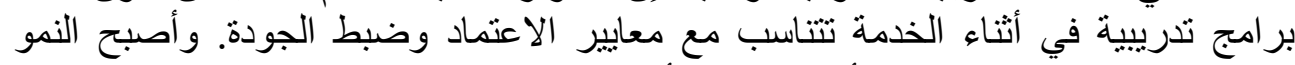

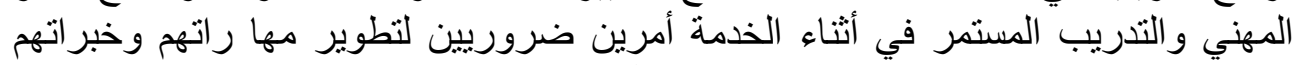

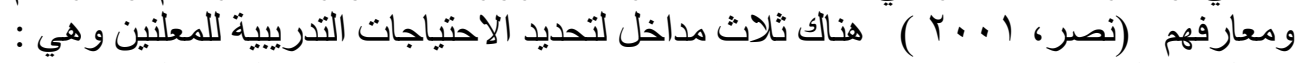

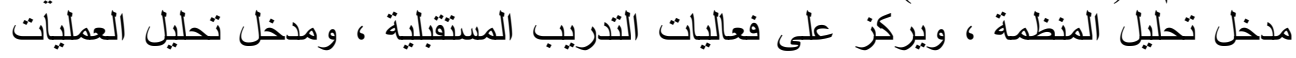

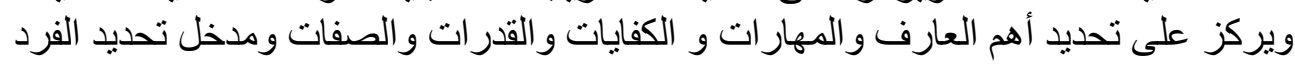


الذي يركز على قياس أداء الفرد في مهارته، وعلى تحديد المعارف و المهار ات والاتجاهات

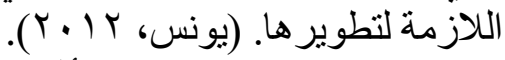

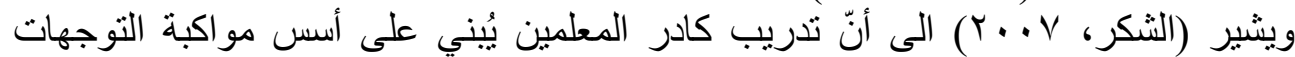

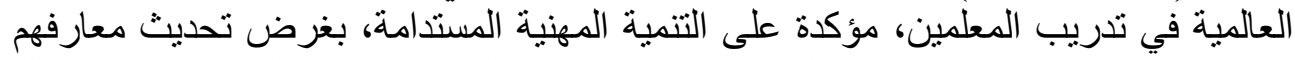

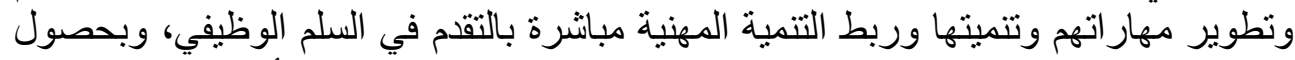

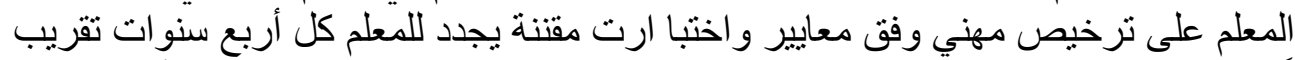

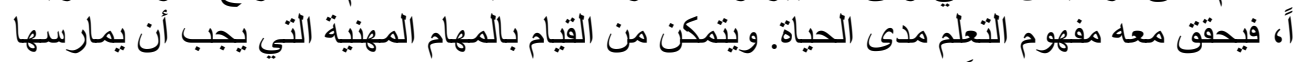

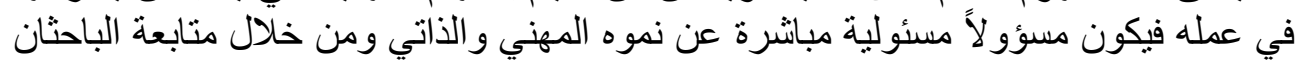

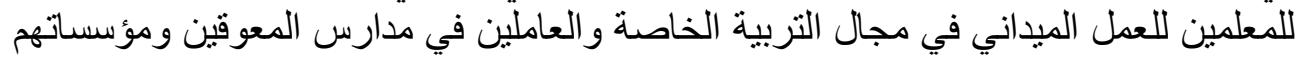

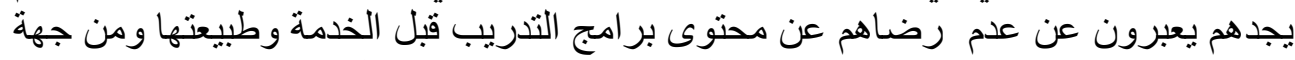

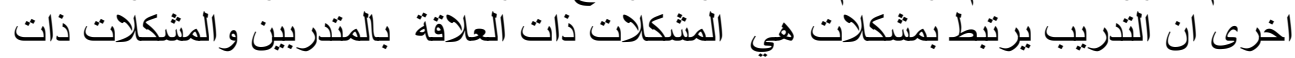
العلاقة بالبرنامج التدريبي.

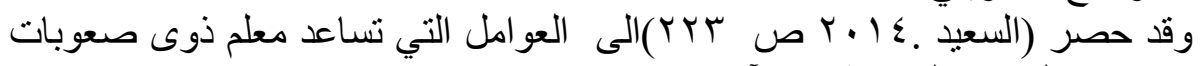

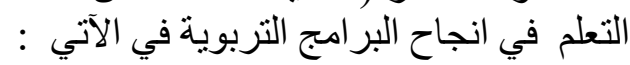

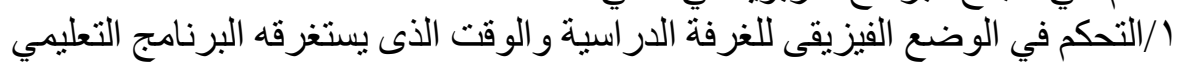

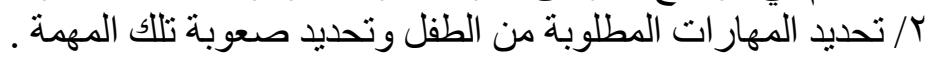

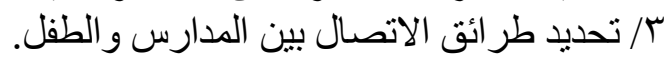

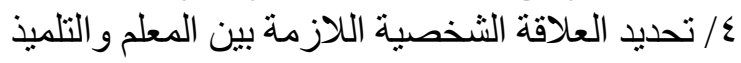

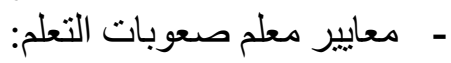

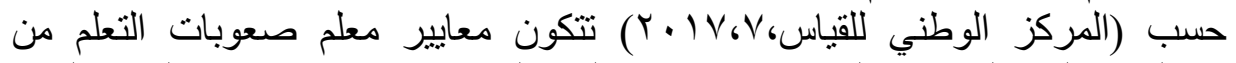

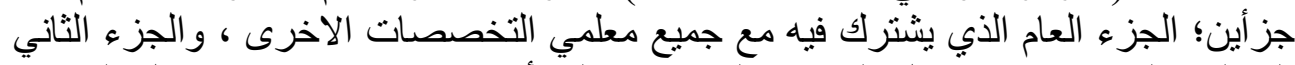

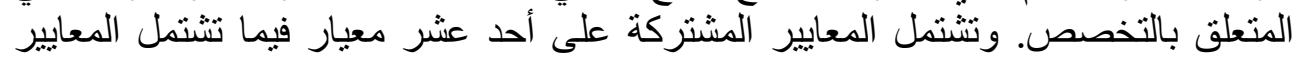

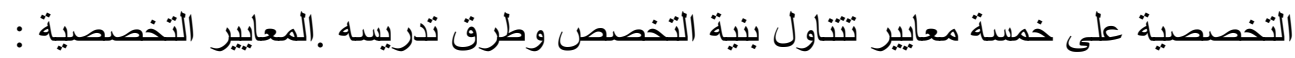

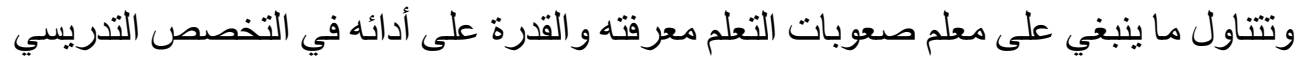

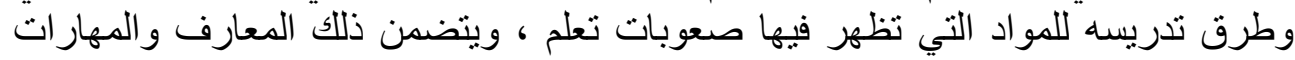

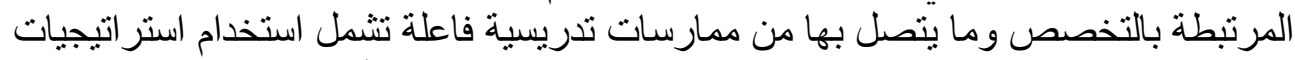

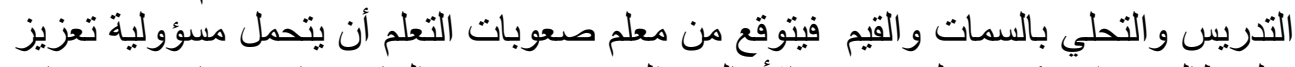

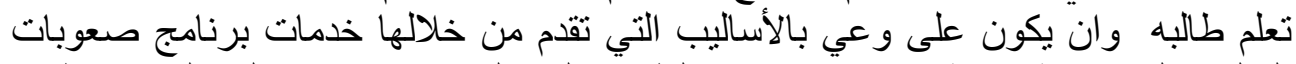

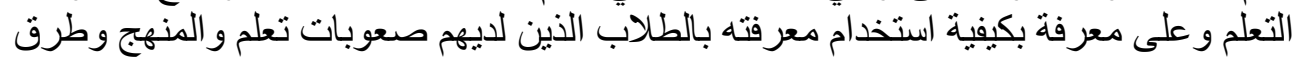

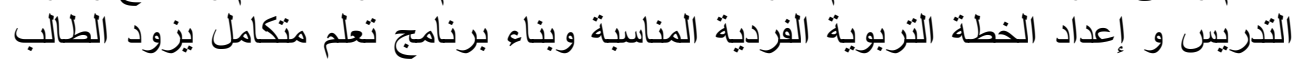

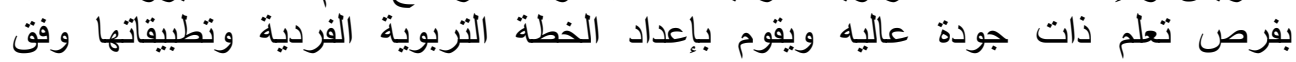
إستر اتيجيات التقويم المتنوعة. 
- مالدات الدابقة (Previous studies):

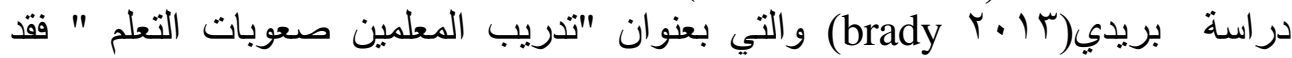

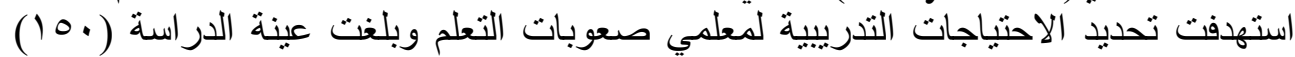

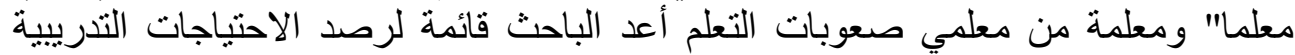

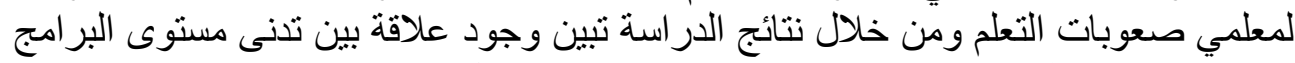

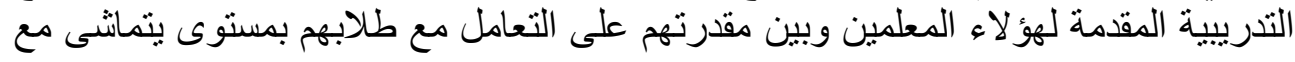

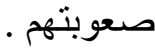

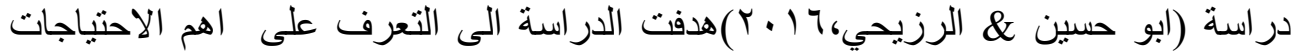

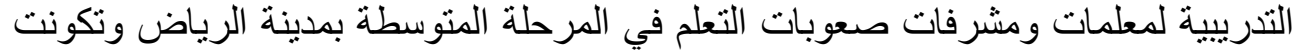

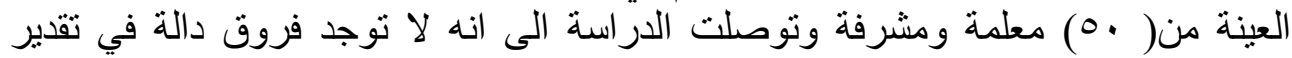

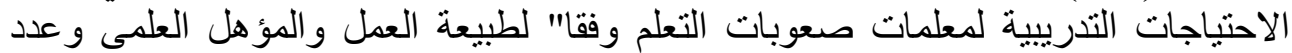

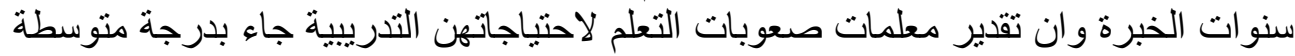

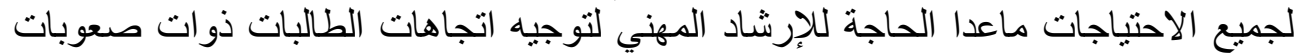

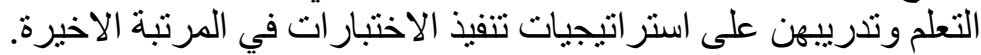

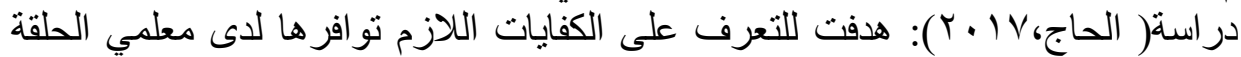

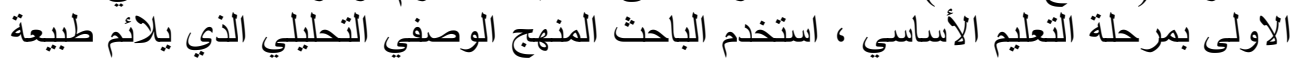

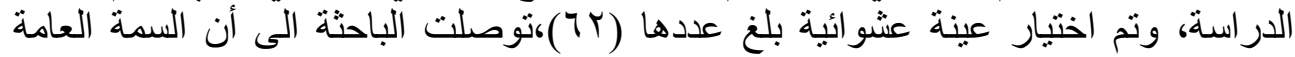

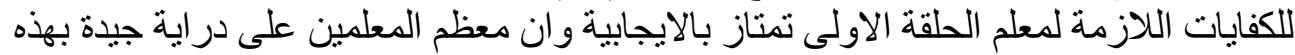

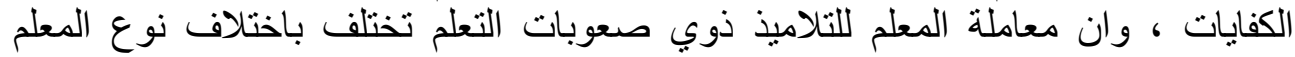

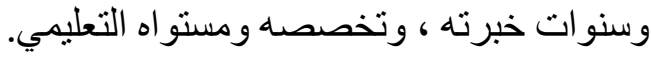

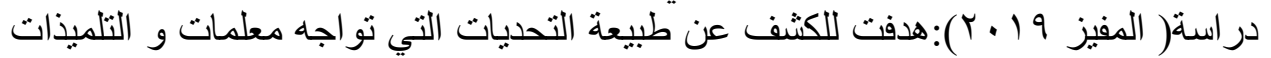

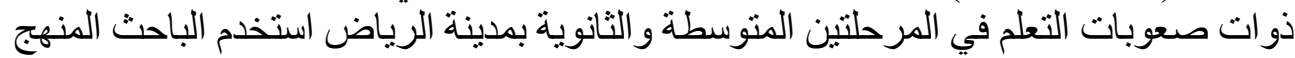

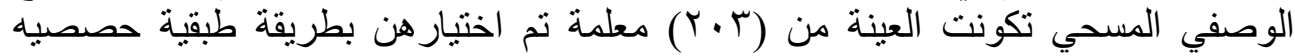

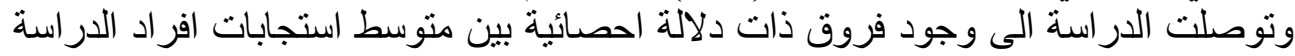

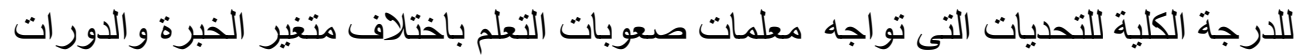

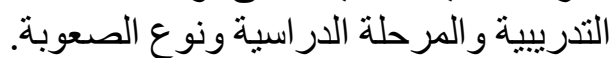

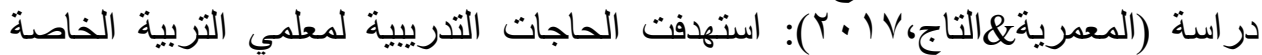

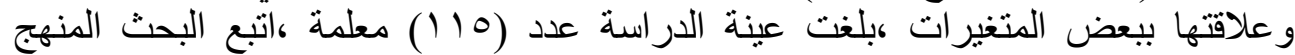

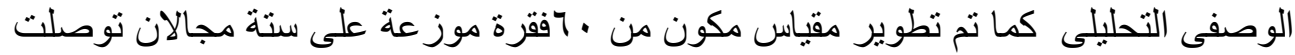

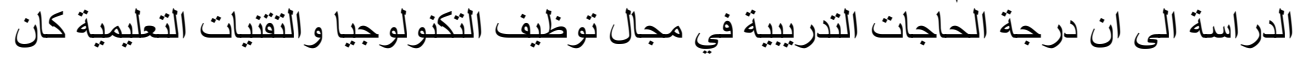

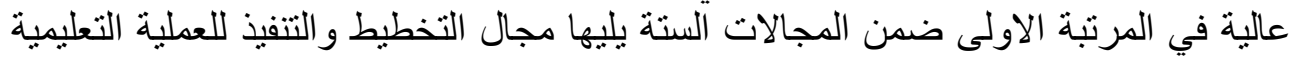

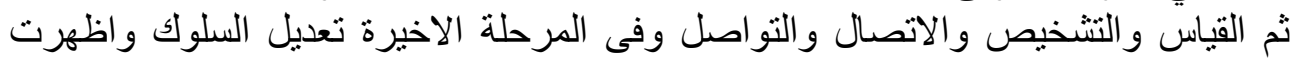


النتائج وجود فروق فردية ذات دلالة احصائية في درجة الحاجات التدرييية للمعلمين باختلاف

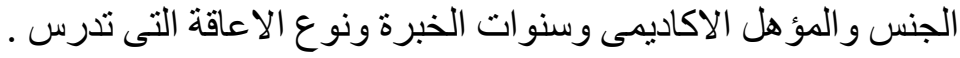

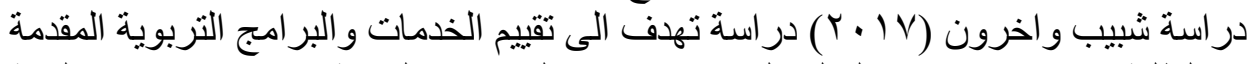

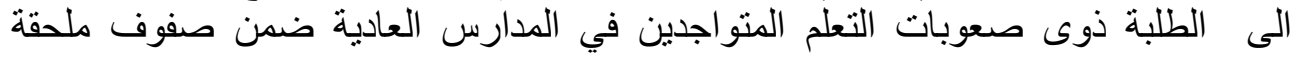

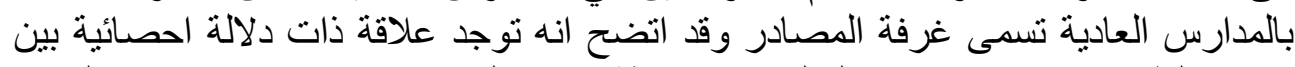

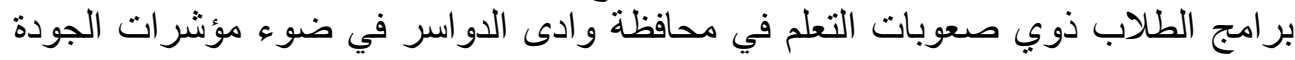

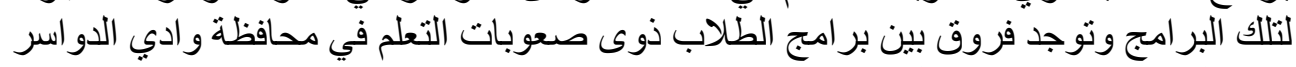
تعود الي سنوات خبرة المعلم. دراسة (2019. Mireille\& Ineke) هدفت الى التحقق من مواقت المعلمين قبل

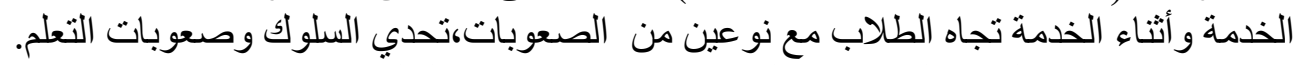

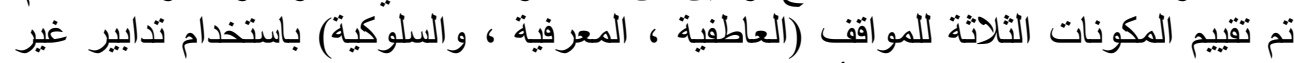

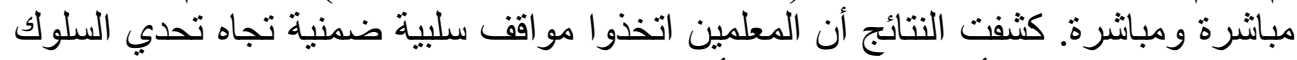

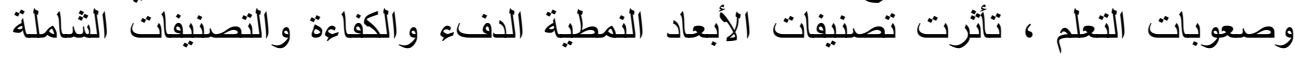

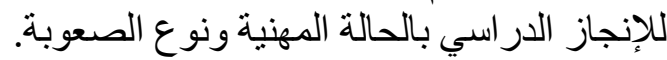

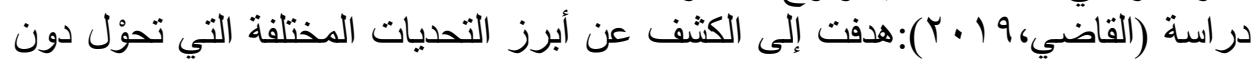

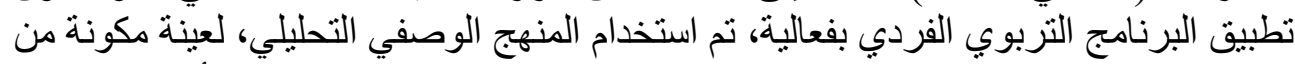

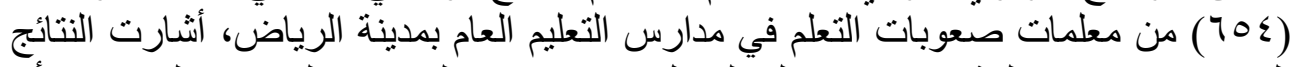

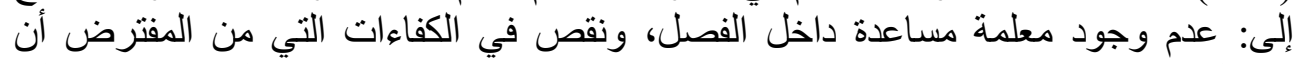

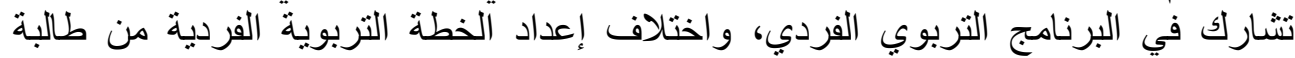

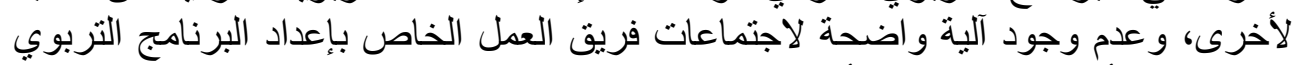

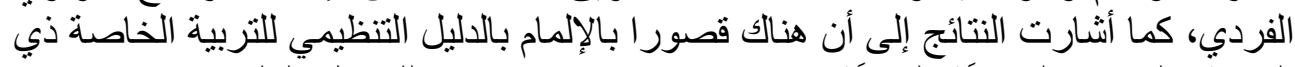

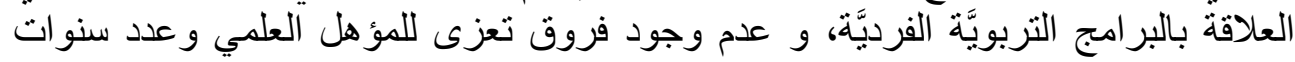

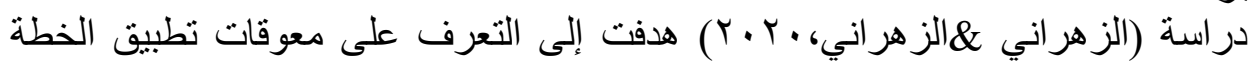

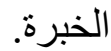

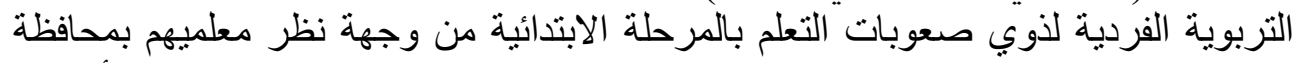

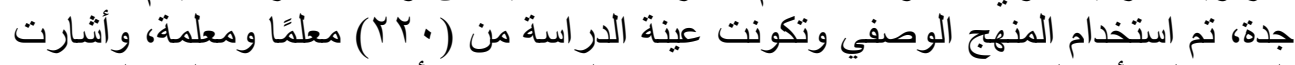

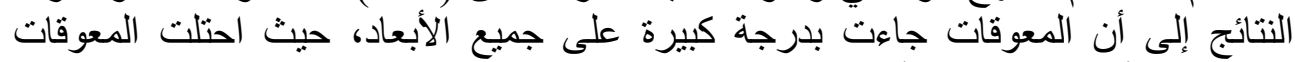

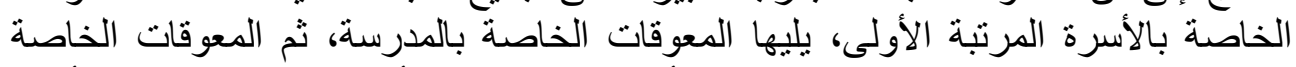

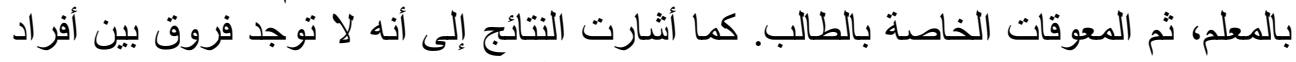

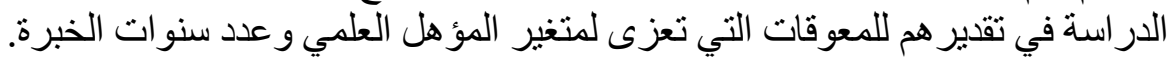




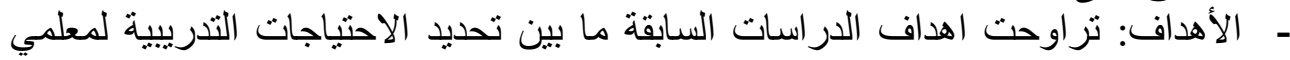

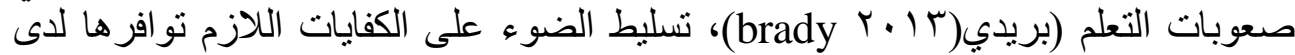

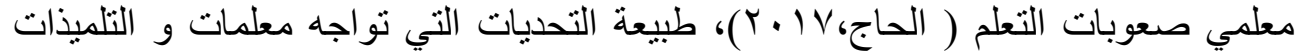

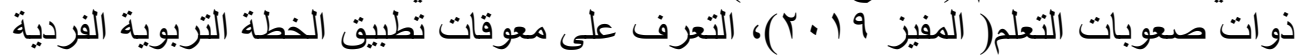

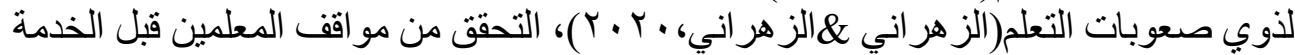
و أثناء الخدمة التحقق من مواقف المعلمين قبل الخدمة و أثناء الخدمة (Mireille\& Ineke).

- -

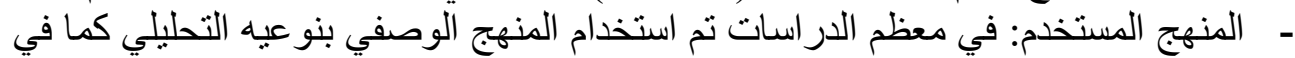

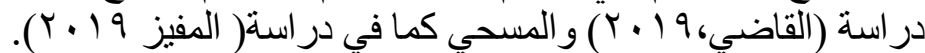

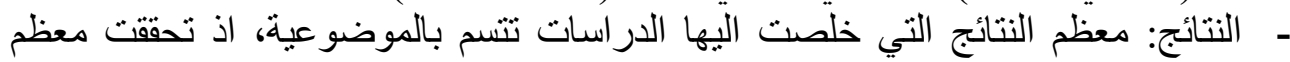

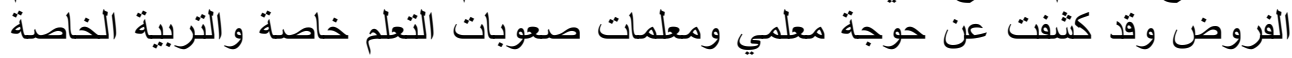

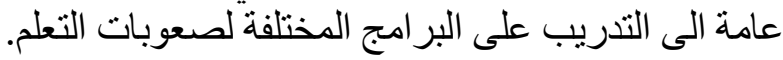

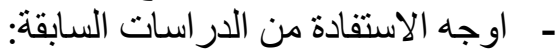

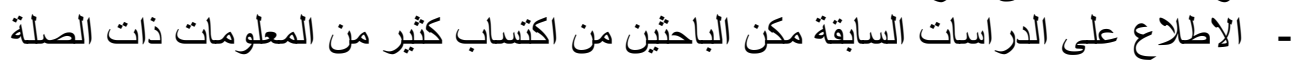

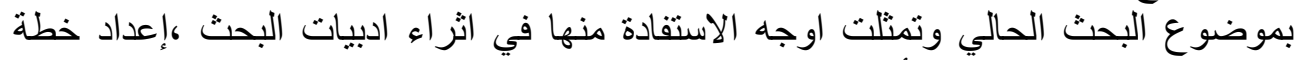

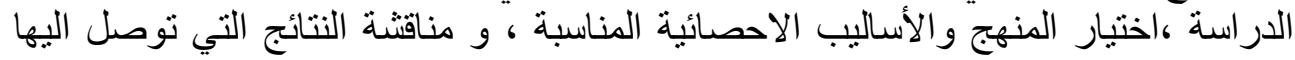

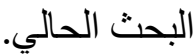

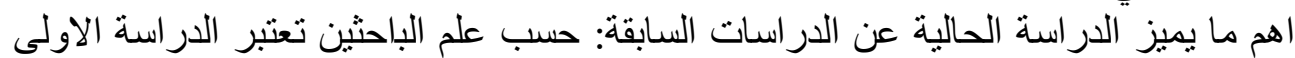

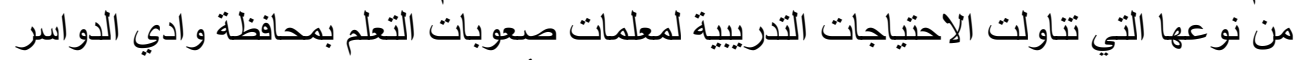

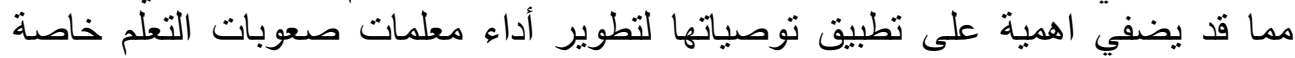

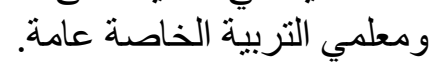

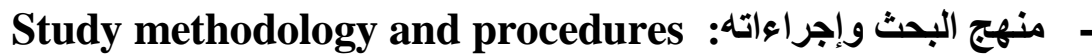

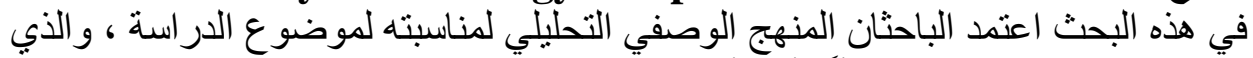

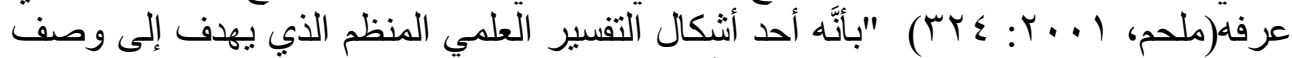

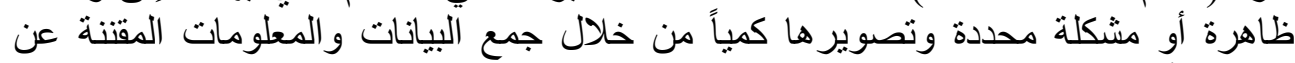

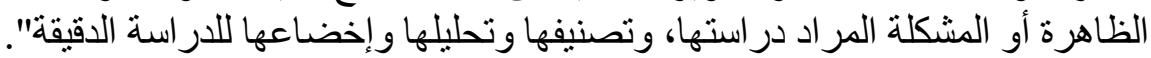
- مجنمع البحث و عينته:Study community and sample -

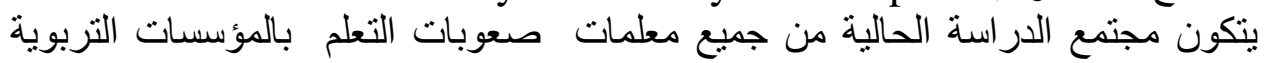

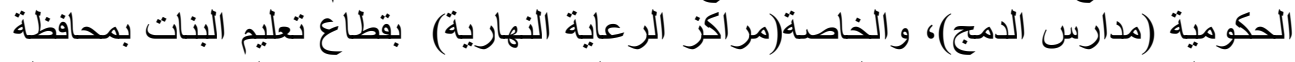

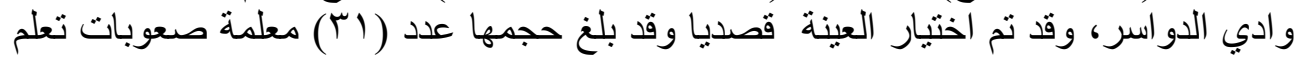




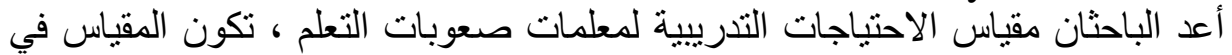

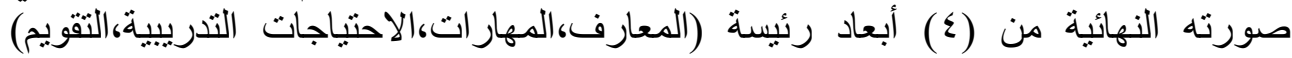

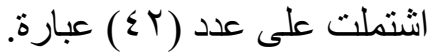
- - صدق وثبات الاسنبيان (Stability and validity):

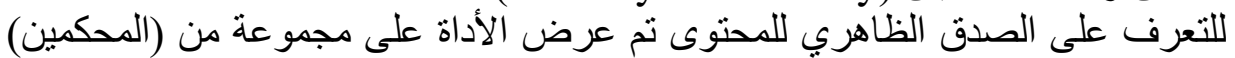

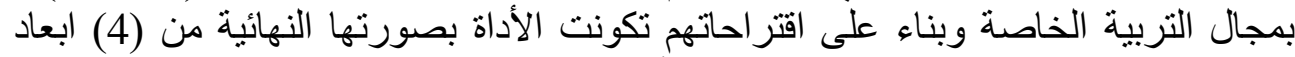

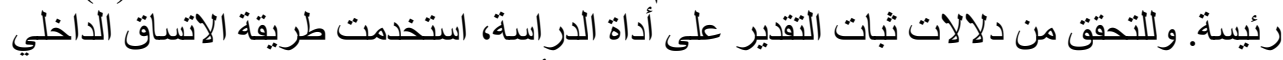

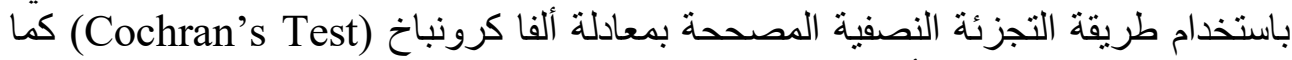

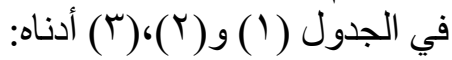

جدول ( ا )معاملات الاتساق الداخلي باستخدام معادلة|ألفا كرونباخ(Cochran's Test)

\begin{tabular}{|c|c|c|}
\hline \multicolumn{3}{|c|}{ Reliability Statistics - } \\
\hline $\begin{array}{c}\mathrm{N} \text { of } \\
\text { Items }\end{array}$ & $\begin{array}{c}\text { Cronbach's Alpha Based on Standardized } \\
\text { Items }\end{array}$ & $\begin{array}{c}\text { Cronbach's } \\
\text { Alpha }\end{array}$ \\
\hline 43 & .973 & .972 \\
\hline
\end{tabular}

\begin{tabular}{|c|c|c|c|}
\hline \multicolumn{4}{|c|}{ Scale Statistics } \\
\hline N of Items & Std. Deviation & Variance & Mean \\
\hline 43 & 20.30991 & 412.492 & 153.6774 \\
\hline
\end{tabular}

جدول(r) يوضح نتائج اختباري انوفاو كرونباخ (ANOVA with Cochran's Test )

\begin{tabular}{|c|c|c|}
\hline \multicolumn{3}{|c|}{ ANOVA with Cochran's Test } \\
\hline \multicolumn{2}{|c|}{ Sig } \\
\hline \multirow{2}{*}{ Between People } & .000 \\
\hline \multirow{3}{*}{ Within People } & Between Items & \\
\cline { 2 - 3 } & Residual & \\
\cline { 2 - 3 } & Total & \\
\hline \multicolumn{2}{|c|}{ Total } \\
\hline
\end{tabular}

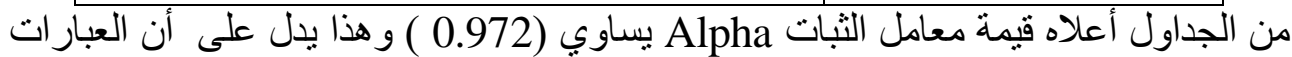

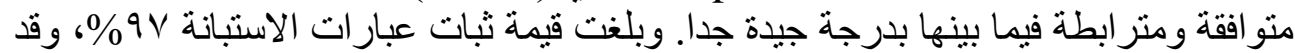

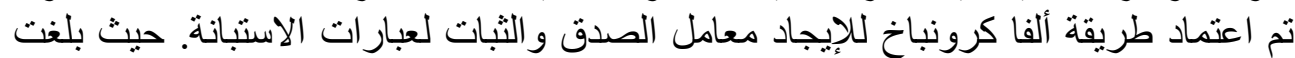
قيمة r المحسوبة لجميع العبارات ( 
مستوي الدلالة 0 . . • )في جميع عبار ات الاستبانة. وبهذا تكون جميع العبار ات صادقة وثابتة ومتسقة داخليا.

جدول رقم (ع ): يوضح أفر اد عينة الدر اسة حسب جهة العمل:

\begin{tabular}{|c|c|c|}
\hline النسبة المئوية & التكر ار & جهة العمل \\
\hline 9.7 & 3 & مدارس خاصة \\
\hline 90.3 & 28 & مدارس حكومية \\
\hline 100.0 & 31 & المجموع \\
\hline
\end{tabular}

شكل ( (): : بوضح أفر اد عينة الدر اسة حسب جهة العمل:

\section{$100.00 \%$
.5}

\section{$9.70 \%$ \\ $90.30 \%$}

مدارس حكوسياتُرس خاصة

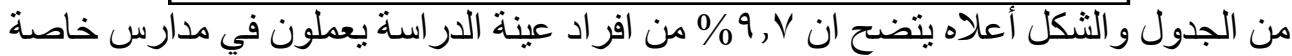

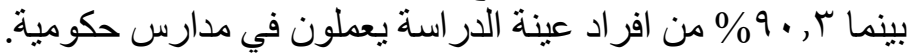

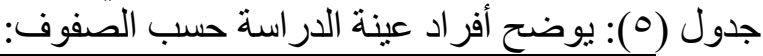

\begin{tabular}{|c|c|c|}
\hline النسبة المئوية & التكرار & الصفوف \\
\hline 48.4 & 15 & أول ـ ثاني ـ ثثالث \\
\hline 32.3 & 10 & رابع - خامس - سادس \\
\hline 19.4 & 6 & سابع - ثامن \\
\hline 100.0 & 31 & المجموع \\
\hline
\end{tabular}

شكل (r): يوضح أفر اد عينة الدر اسة حسب الصفوف:

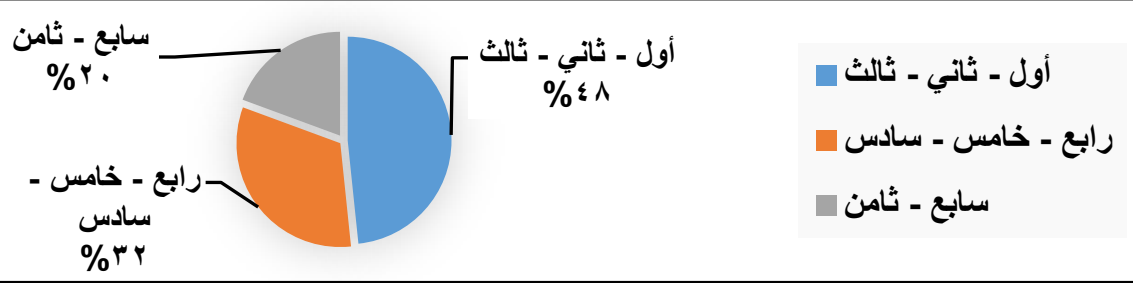

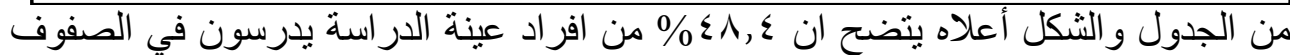

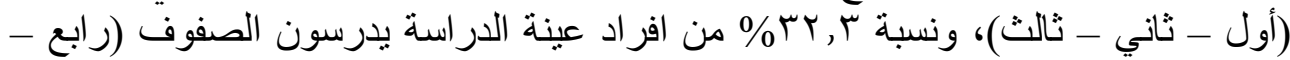
خامس - سأدس) بينما ؟ , 9 (\% من افر اد عينة الدر اسة يدرسون المر احل (سابع وثامن). 
جدول رقم (ך): يوضح أفر اد عينة الدر اسة حسب المؤهل العلمي:

\begin{tabular}{|c|c|c|}
\hline النسبة المئوية & التكر ار & المؤهل العلمي \\
\hline 32.3 & 10 & أخرى \\
\hline 48.4 & 15 & تربية عامة \\
\hline 9.7 & 3 & تربية أساس \\
\hline 9.7 & 3 & تربية خاصة \\
\hline 100.0 & 31 & المجموع \\
\hline
\end{tabular}

- شكل (r): يوضح أفر اد عينة الدر اسة حسب المؤ هل العلمي:

\begin{tabular}{|c|c|c|c|c|}
\hline \multirow{2}{*}{$50.00 \%$} & \multicolumn{2}{|c|}{$48.40 \%$} & & \\
\hline & & & $9.70 \%$ & \\
\hline $0.00 \%$ & أخرى & تربية عامة & تربية أساس & تربية خاصة \\
\hline
\end{tabular}

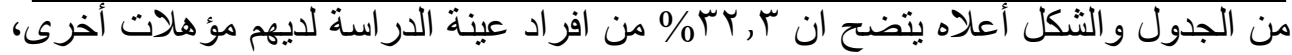

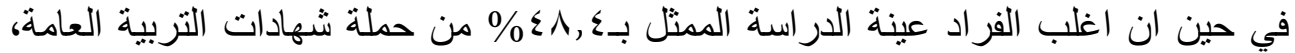

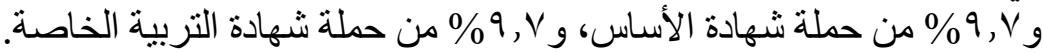

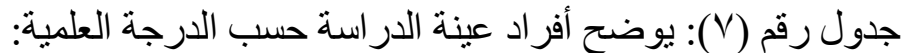

\begin{tabular}{|c|c|c|}
\hline النسبة المئوية & التكر ار & الدرجة العلمية \\
\hline 80.6 & 25 & بكالوريوس \\
\hline 19.4 & 6 & دبلوم عالي \\
\hline 100.0 & 31 & المجموع \\
\hline
\end{tabular}

شكل رقم (ع): يوضح أفر اد عينة الدر اسة حسب الدرجة العلمية:

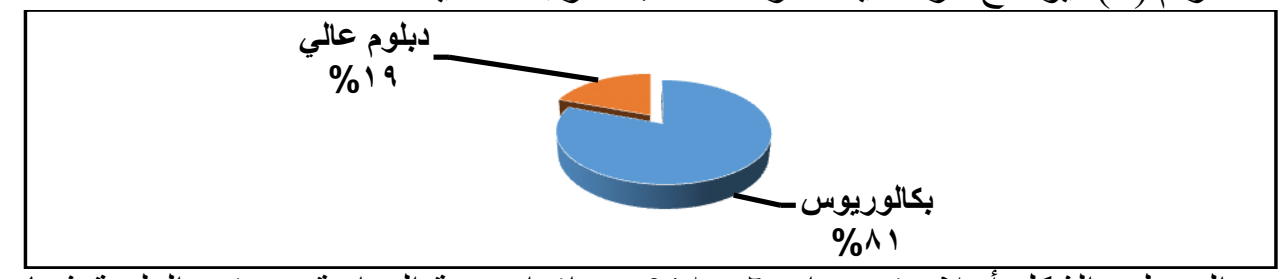

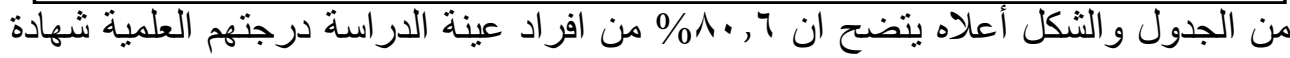

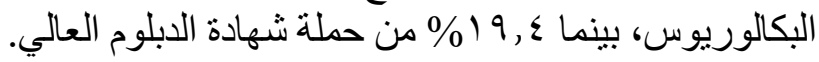


جدول رقم (^): يوضح أفر اد عينة الدر اسة حسب المو اد:

\begin{tabular}{|c|c|c|}
\hline النسبة المئوية & التكر ار & المو اد \\
\hline 51.6 & 16 & لغة عربية \\
\hline 32.3 & 10 & رياضيات \\
\hline 16.1 & 5 & أخرى \\
\hline 100.0 & 31 & المجموع \\
\hline
\end{tabular}

- ـ شكل رقم (0): يوضح أفر اد عينة الدر اسة حسب المو اد:

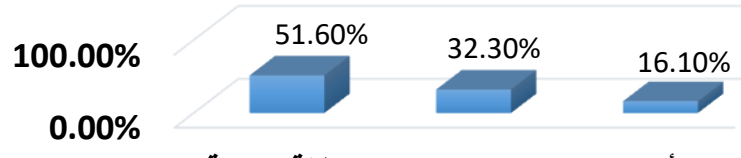

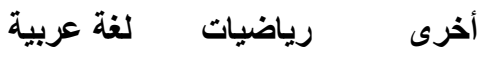

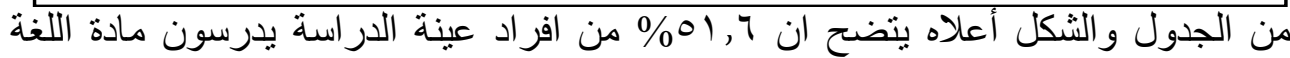

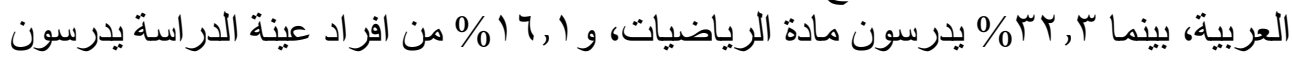

جدول رقم (9): يوضح أفر اد عينة الدر اسة حسب سنوات الخبرة:

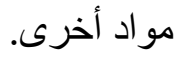

\begin{tabular}{|c|c|c|}
\hline النسبة المئوية & التكرار & سنو ات الخبرة \\
\hline 87.1 & 27 & 5 سنو ات فأقل \\
\hline 12.9 & 4 & 10 - 6 سنو ات \\
\hline 0 & 0 & 16 سنة فما فوق \\
\hline 100.0 & 31 & المجموع \\
\hline
\end{tabular}

- شكل رقم (7): يوضح أفراد عينة الدر اسة حسب سنوات الخبرة:

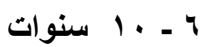

\% 1T
17 سنة فما فوق آن

$\%$.

م سنوات فأقل

$\% \wedge \vee$

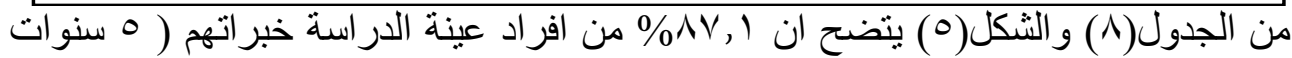

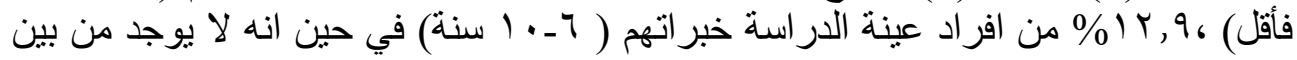

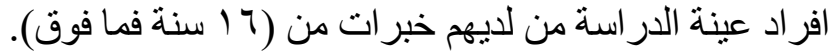
- أساليب المعالجة الإحصائية (Statistical processing methods): - معامل ارتباط بيرسون (Pearson's Correlation) - 
- معادلة الفا كرونباخ (Cronbach's Alpha) - - - مداول التوزيع التكر اري (Cross tabulation-count) - اختبار(ت) لدالة الفروق (T-Test Independent Samples Test) -

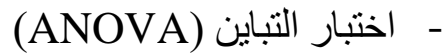

نتاج البحث ومناقشتها (Search Results and Discussion): عرض ومناقتنة الفرض الأول الذي نصانه: (يتسم تقدير مستوى الحاجات التدريبية لمعلمات

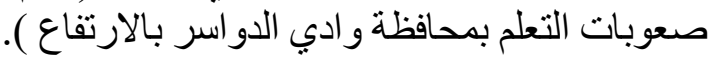
جدول ( • ()يوضح الفروقات في الوسط الحسابي و الانحر اف المعياري للعبار ات في مجال

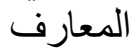

\begin{tabular}{|c|c|c|c|}
\hline الخطباري & |لالانحراف & العددالآلوسابي & العبار ات \\
\hline .09890 & .55066 & 3.645231 & التعلم الإلمام باللو ائح و الأنظمة المدرسية الخاصة ببرامج ذوي صعوبات \\
\hline .08932 & 49730 & \begin{tabular}{l|l|l}
3.7742 & 31 \\
\end{tabular} & إدر الك مفهوم صعوبات التعلم \\
\hline .11541 & .64258 & \begin{tabular}{|l|l|l}
3.7097 & 31 \\
\end{tabular} & التعرف على أنو اع صعوبات التعلم \\
\hline .14330 & .79785 & 3.645231 & معرفة أسباب صعوبات التعلم \\
\hline .11541 & .64258 & \begin{tabular}{l|l|l}
3.7097 & 31 \\
\end{tabular} & التعرف على سمات ذوي صعوبات التعلم \\
\hline .14546 & .80989 & $3.4516 \quad 31$ & إدراك خصائص النمو لذوب صعوبات التعلم \\
\hline .11206 & 62390 & \begin{tabular}{l|l|l}
3.5484 & 31 \\
\end{tabular} & الإحاطة باستر اتيجيات تدريس ذوي صعو بات التعلم \\
\hline .13090 & .72882 & \begin{tabular}{|l|l|l}
3.7419 & 31 \\
\end{tabular} & التعرف على الفرق بين صعوبات التعلم و التأخر الدراسي \\
\hline .11143 & 62044 & 3.580631 & الإلمام بإجر اءات و أساليب التعرف على صعوبات التعلم \\
\hline .14426 & .80322 & \begin{tabular}{l|l|l}
3.3871 & 31 \\
\end{tabular} & إكتساب أساليب تقويم ذوي صعوبات التعلم \\
\hline 13661 & .76059 & $\begin{array}{l}3.6129 \\
31 \\
\end{array}$ & إدراك الفرق بين طرق تدريس العاديين وذوي صعوبات التُعلم \\
\hline .11867 & 66073 & \begin{tabular}{l|l}
3.6452 & 31 \\
\end{tabular} & التنريب على وسائل تنمية دافعية التعلم لدى ذوي صعوبات التعلم \\
\hline 14426 & .80322 & 3.387131 & ذأنعري صعو عاتى الطعلمق الفعالة لتعديل إتجاهات المتفوقين العاديين نحو \\
\hline 10064 & .56034 & $\begin{array}{lll}3.7742 & 31\end{array}$ & المختلفة على طرق تشجيع ذوي صعوبات التعلم في الأنشطة \\
\hline
\end{tabular}

من خلال عبارات المحور اتضح ان العبارات التالية سجلت اعلى متوسطات وهي: (ادراك

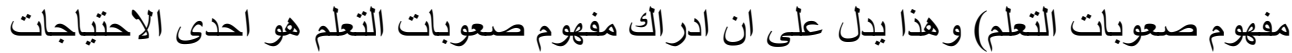
التدرييية. ثم أتت العبارة التي تتص على (التعرف على طرق تنتجيع ذوى صعوبات التعلم في التيات 


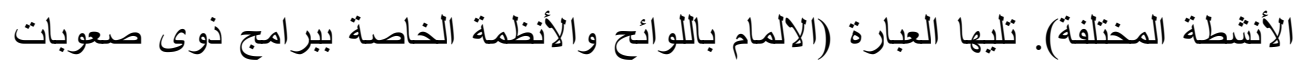

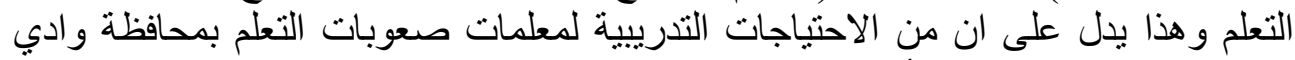

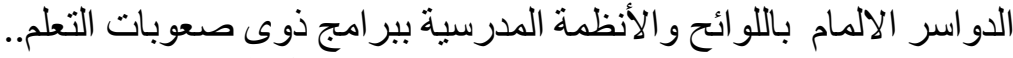

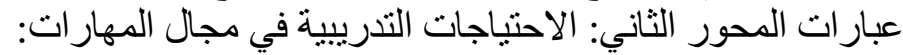
جدول رقم (11): يوضح الفروقات في الوسط الحسابي والانحراف المئيات المعياري لعبارات في

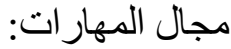

\begin{tabular}{|c|c|c|c|c|}
\hline |الخطاء & الالمعياري افي & |الحسطي الوسي & & $\ddot{3}$ \\
\hline .11983 & .66720 & 3.6129 & 31 & 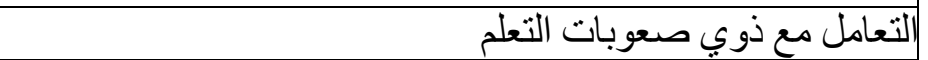 \\
\hline .11983 & .66720 & 3.6129 & 31 & مناسبة لذوي صعوبات التعلم \\
\hline .15358 & .85509 & 3.2581 & 31 & تصب أهدهج بما يتو افق مع خصائص وحاجات ذوي \\
\hline .11206 & .62390 & 3.5484 & 31 & لفيمية بصورة تساعد ذوي صعوبات التعلم المشاركة \\
\hline .10568 & .58842 & 3.7 & 31 & بوبات التعلم الوسئل التعليمية بما يتتاسب مع خصائص وحاجات ذوي \\
\hline 30 & .71 & 3.5806 & 31 & م أدوات للتقويم مناسبة لذوي صعوبات التعلم \\
\hline .12984 & .72290 & 3.4516 & & ي صعوبات التعلم \\
\hline .18606 & 1.03591 & 3.1613 & 31 & لحاسب الآلي في ت \\
\hline .08287 & .46141 & 3.7097 & 31 & عوبات التعلم على الإل \\
\hline 59 & 491 & 3.6452 & 31 & مساعدة صعوبات التعلم على تعميم المهار \\
\hline & & & 31 & إعداد الخطة التربوية الفردية ذوي صعوبات التعلم \\
\hline .11983 & .66720 & 3.6129 & 31 & وبات التعلم \\
\hline
\end{tabular}

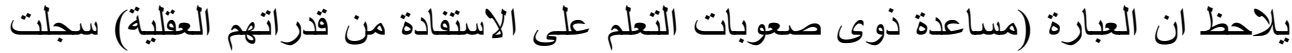

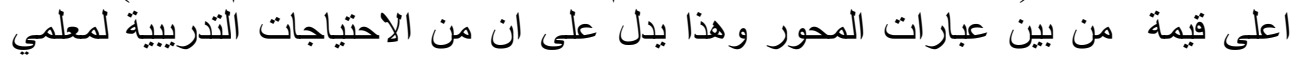

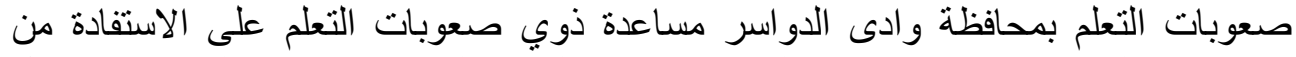

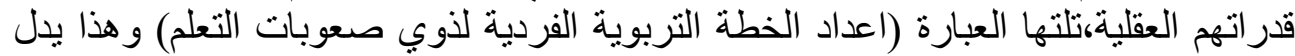

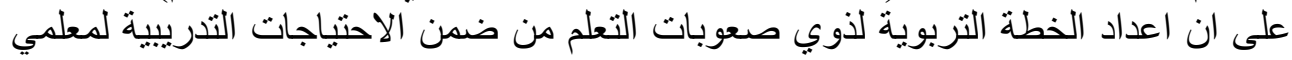

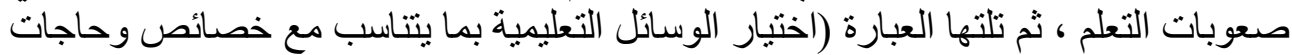

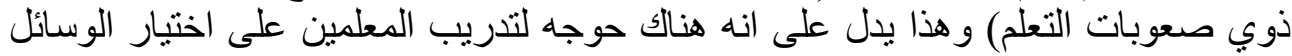

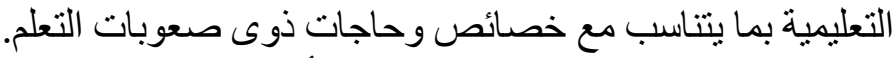
- المحور الثالث: الاحتياجات التدريبية الأساسية: 
جدول رقم (r ( ) : يوضح الفروقات في الوسط الحسابي والانحر اف المعياري لعبارات حول الاحتياجات التدريبية الأساسية: - الانحراف

\begin{tabular}{|c|c|c|c|c|}
\hline المعياري & 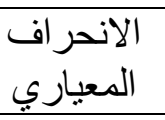 & الحسابي & العدد & العبارات \\
\hline .08161 & .45437 & 3.8387 & 31 & تقبل وجود برنامج ذوري صعو بات التعلم \\
\hline .06715 & .37388 & 3.8387 & 31 & تطوير قدر اتي في مجات التعلم تدريس ذوب \\
\hline .10336 & .57548 & 3.7419 & 31 & إكساب مهارات التفاعل الإيجابي مع ذوي \\
\hline .08575 & .47745 & 3.8065 & 31 & تطوير مهارات التفاعل مع البيئة التعليمية \\
\hline 10064 & .56034 & 3.7742 & 31 & مساعدة ذوي صعو بات التعلم لتقبل برامج \\
\hline .11983 & .66720 & 3.3871 & 31 & مساعدة أسر ذوي صعوبات إيجات التعلم لتكوين \\
\hline
\end{tabular}

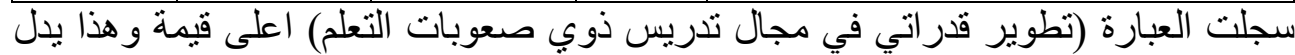

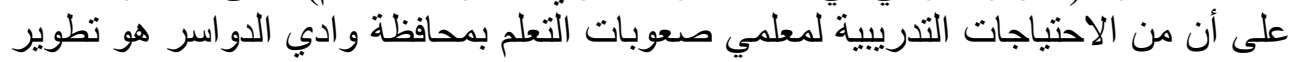

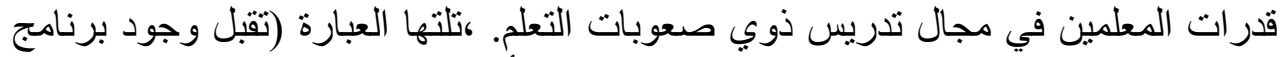

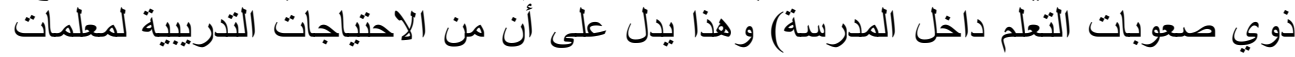

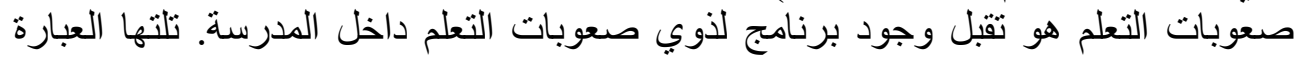

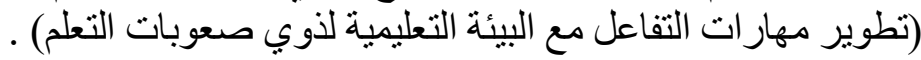

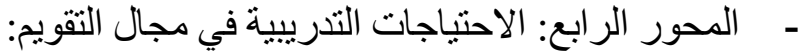

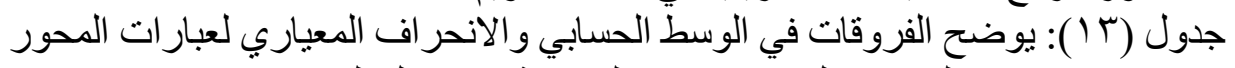

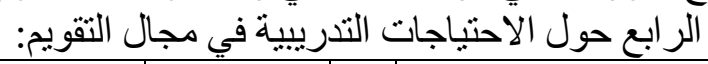

\begin{tabular}{|c|c|c|c|c|}
\hline المباري المياء & ال الانحراف & المسابي & العدد & العبار ات \\
\hline .14330 & .79785 & 3.6452 & 31 & تشخيص ذوي صعوبات التعلم \\
\hline .14570 & .81121 & 3.4839 & 31 & الكثف عن حاجات ذوي صعوبات التعلم \\
\hline .13010 & .72438 & 3.5161 & 31 & إختبار فعالية الطر ائق و الأساليب التندريسية \\
\hline
\end{tabular}


Doi: 10.21608/jasht.2021.161836

هنادي/إبراهيه - د.سمر ميرغني

\begin{tabular}{|c|c|c|c|c|}
\hline .14546 & .80989 & 3.5484 & 31 & التأكد من مدى تحقق الأهداف التربوية \\
\hline .13010 & .72438 & 3.4839 & 31 & تصميم خطط إرشادية لذوي صعوبات التعلم \\
\hline .13090 & .72882 & 3.2581 & 31 & تحديد معايير تشخيص ذوي صعوبات التعلم \\
\hline .14330 & .79785 & 3.3548 & 31 & بناء إختبار ات موضو عية لذوي صعوبات \\
\hline .12849 & .71542 & 3.3871 & 31 & تقييم ذوي صعوبات التعلم حسب سيرورة \\
\hline .15649 & .87129 & 3.3226 & 31 & بناء أسئلة جزئية آنية عاجلة و ملائمة لذوي \\
\hline .13010 & .72438 & 3.4839 & 31 & إدر اج أسئلة تتو افق وقدر ات صعوبات التعلم \\
\hline .12984 & .72290 & 3.5484 & 31 & تطبيق برنامج التقويم المستمر مع ذوي \\
\hline
\end{tabular}

سجلت العبارة (تطبيق برنامج التقويم المستمر مع ذوي صعوبات التعلم) سجلت اعلى قيمة

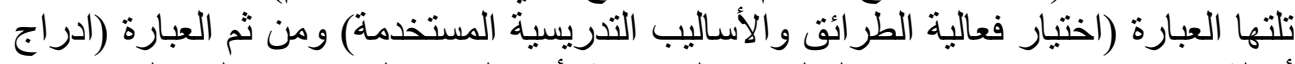

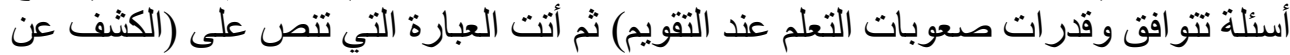

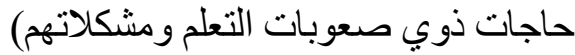
مناقثة نتيجة الفرض الاول:

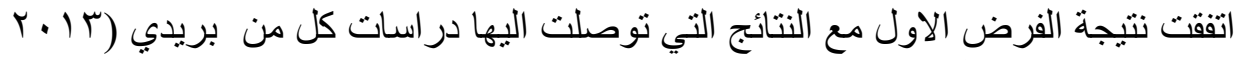

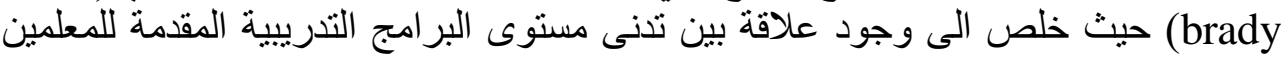

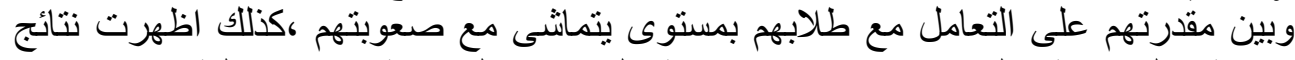

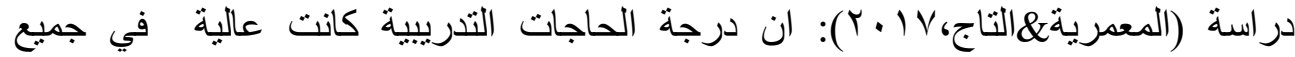

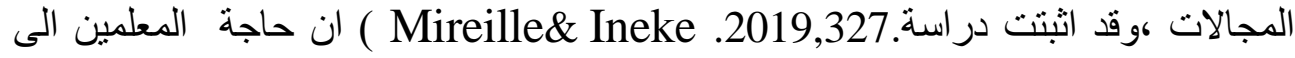

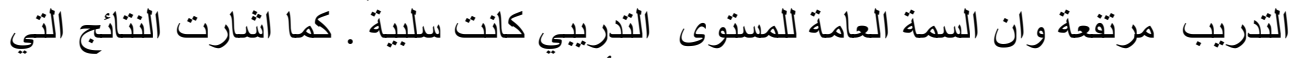

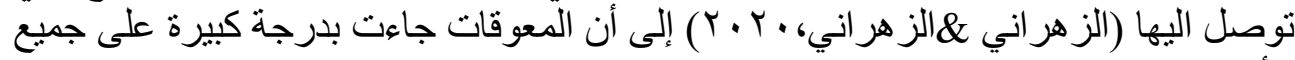
الأبعاد.

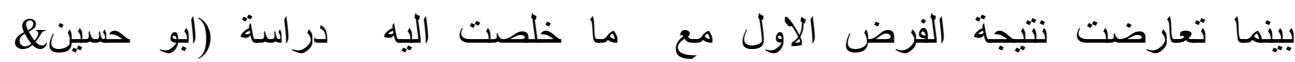

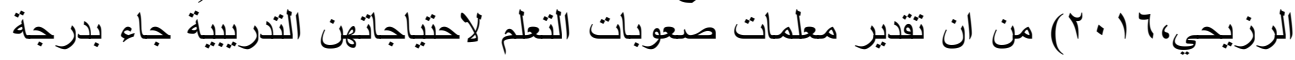

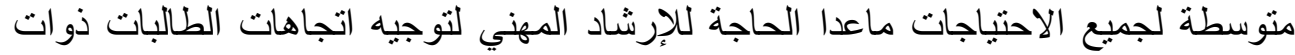

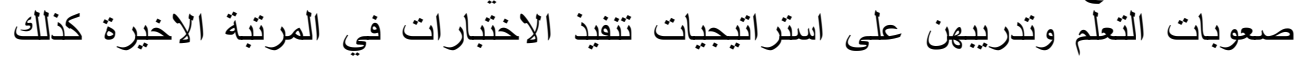

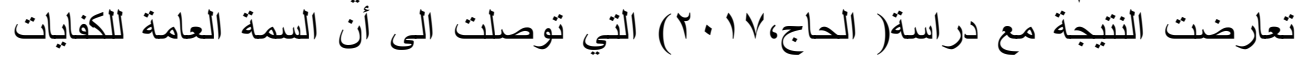


اللازمة لمعلم الحلقة الاولى تمتاز بالايجابية وان معظم المعلين على دراية جيذة بهذه

الكفايات.

عرض ومناقثة نتيجة الفرض الثاني الذي نصه (توجد فروق في تقدير الاحتياجات التدريبية

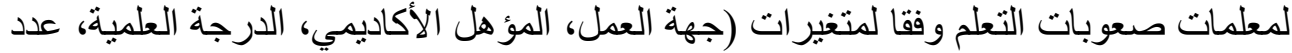
سنوات الخبرة، الصفوف التي تقوم بتدريسها و المواد التي تقوم بتدريسها).

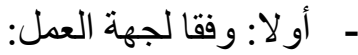
- جدول رقم (ع ()): يوضح الفروقات في الوسط الحسابي بين محاور التدريب وجهة العمل

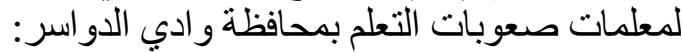
المتوسطات الحسابية

\begin{tabular}{|c|c|c|c|c|}
\hline \multicolumn{5}{|c|}{ المتوسطات الحسابية } \\
\hline الانحر اف المعباري & الوسط الحسبابي & العدد & جهة العمل & المحاور \\
\hline .67847 & 3.6429 & 28 & مدارس حكو مبة & \multirow{2}{*}{ محور المعارف } \\
\hline .57735 & 3.6667 & 3 & مدارس خاصة & \\
\hline .61183 & 3.6786 & 28 & مدارس حكومية & \multirow{2}{*}{ محور المهار ات } \\
\hline .57735 & 3.6667 & 3 & مدارس خاصة & \\
\hline .46004 & 3.7143 & 28 & مدارس حكو مية & \multirow{2}{*}{ محور الاحتياجات } \\
\hline .00000 & 4.0000 & 3 & مدارس خاصة & \\
\hline .79349 & 3.5000 & 28 & مدارس حكومية & \multirow{2}{*}{ محور التقويم } \\
\hline .57735 & 3.6667 & 3 & مدارس خاصة & \\
\hline
\end{tabular}

- من الجدول أعلاه يتضح أنه توجد فروقات في الوسط الحساب الحسب بين وداخل جميع المحاور

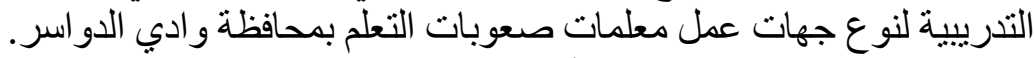

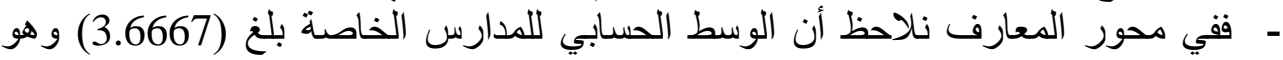

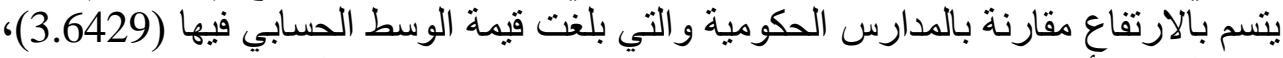

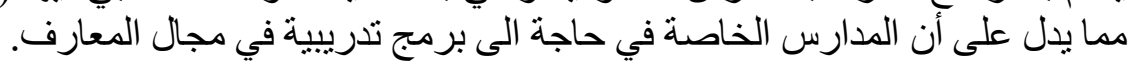

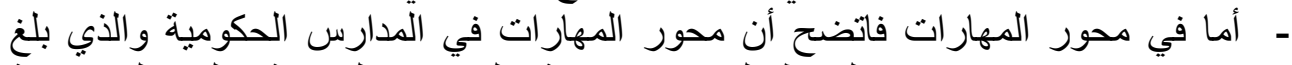

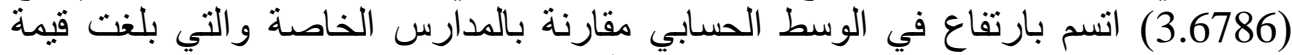

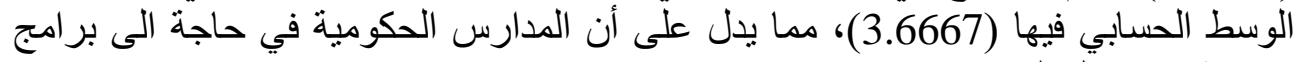

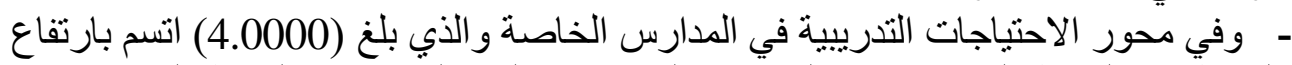

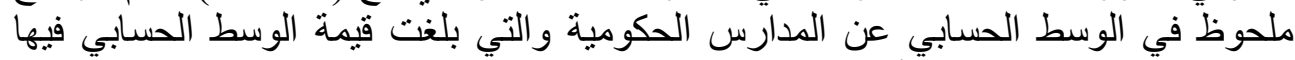

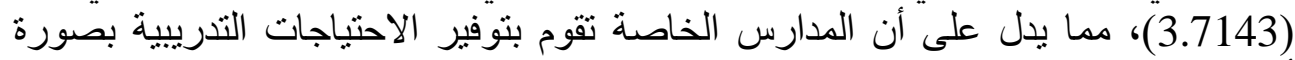
أفضل من المدارس الحكومية. 
- ـ وفي محور التقويم نلاحظ أن محور التقويم في المدارس الخاصة والذي بلغ (3.6667)

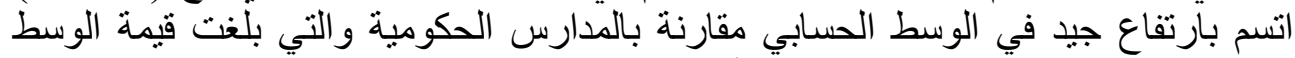
الحسابي فيها (3.5000)، مما يدل على أن المدارس الخاصة في حاجة التى بر امج تدريبية في لفي مجال التقويم. - جدول رقم 10): بوضح الفروقات ذات الدالة الإحصائية بواسطة اختبار التباين بين عبار ات محاور التدريب وجهة العمل لمعلمات صعوبات الاتبة التعلم بمحافظة

\begin{tabular}{|c|c|c|c|c|c|c|c|c|c|}
\hline \multicolumn{10}{|c|}{ اختبار التباين } \\
\hline \multicolumn{2}{|c|}{ الثقة عند نسبة 90\% } & \multirow{2}{*}{ المتوسطات } & \multirow{2}{*}{\begin{tabular}{|c|} 
الاحتمالية \\
القيمة \\
\end{tabular}} & \multirow{2}{*}{ الحرجة } & \multirow{2}{*}{ قالمحسوبة (ت) } & \multirow{2}{*}{$\begin{array}{c}\text { الاحتمالية } \\
\text { القيمة) } \\
\end{array}$} & \multirow{2}{*}{ القيمة (ف) } & \multirow{2}{*}{\multicolumn{2}{|c|}{ المحاور }} \\
\hline |أعلى قيمة & أقل قيمة & & & & & & & & \\
\hline .81110 & .85872 & .02381 & .954 & 29 & .058 & & & |الفروق & \\
\hline $\mid 1.20839$ & 1.25601 & .02381 & .952 & 2.631 & .067 & .705 & .147 & |الفنسير & المعارف \\
\hline .76921 & .74540 & .01190 & .975 & 29 & .032 & & & |الفروقة |لفتة & \\
\hline 1.27039 & 1.24658 & .01190 & .976 & 2.508 & .034 & .863 & .030 & الكتبر الفيرة & المهارات \\
\hline 26581 & .83724 & .28571 & 298 & 29 & 1.060 & & & |الفرساو ية & محور \\
\hline .10733 & .46410 & .28571 & .003 & 27.000 & 3.286 & .001 & 3 & |الفير & التدريبية \\
\hline .80309 & 1.13642 & .16667 & .728 & 29 & .352 & & & 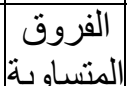 & \\
\hline 1.02379 & 1.35713 & .16667 & .681 & 2.883 & .456 & -459 & .562 & |المنسير & التقويم \\
\hline
\end{tabular}

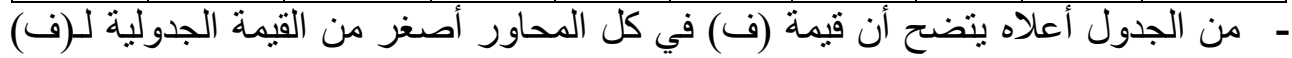

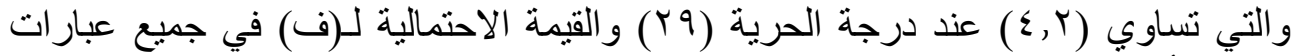

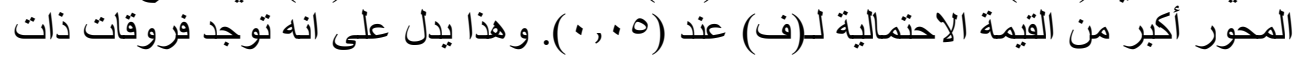


دلالة إحصائية وتباين بين المحاور في الاحتياجات التدريبية لمعلمات صعوبات التعلم بمحافظة

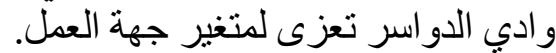
- - ثانيا: وفقا للمؤهل الأكاديمي:

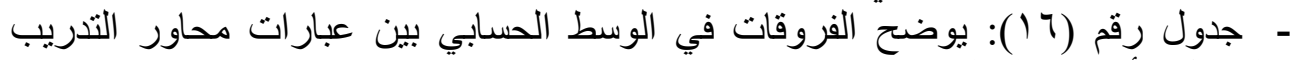

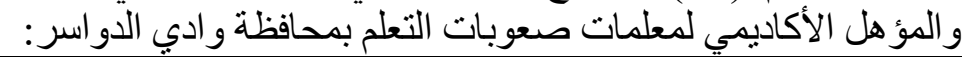

\begin{tabular}{|c|c|c|c|c|c|c|c|c|c|}
\hline \multicolumn{10}{|c|}{ وسطات الحسابية } \\
\hline & & لحسب لحسبي من & مقدار الثق مد & |الخعيارئ & الالنحرياري & الوسط & & \multirow{2}{*}{\multicolumn{2}{|c|}{ المحاور }} \\
\hline & & أعلى وزن & أقل وزن & & & & & & \\
\hline 4.00 & 2.00 & 3.9733 & 3.4667 & 2275 & .61373 & 7200 & 25 & بكالو & \multirow{3}{*}{ المعارف } \\
\hline 4.00 & 2.00 & 4.1902 & 2.4765 & 33333 & .81650 & 3.3333 & 6 & دبلوم عالي & \\
\hline 4.00 & 2.00 & 3.8875 & 3.4028 & 11867 & .66073 & 3.6452 & 31 & & \\
\hline 4.00 & 2.00 & 3.9758 & 3.5442 & 10456 & .52281 & 3.7600 & 25 & بكالور & \multirow{3}{*}{ المهار ات } \\
\hline 4.00 & 2.00 & 4.1902 & 2.4765 & 33333 & .81650 & 3.3333 & 6 & دبلوم عالي & \\
\hline 4.00 & 2.00 & 3.8972 & 3.4576 & 10763 & .59928 & 3.6774 & 31 & & \\
\hline 4.00 & 3.00 & 3.9399 & 3.5801 & 08718 & .43589 & 3.7600 & 25 & بكالوريوس & \multirow{3}{*}{ الاحتياجات } \\
\hline 4.00 & 3.00 & 4.2086 & 3.1247 & 21082 & .51640 & 3.6667 & 6 & دبلوم عالي & \\
\hline 4.00 & 3.00 & 3.9051 & 3.5788 & .07989 & .44480 & 3.7419 & 31 & المجموع & \\
\hline 4.00 & 2.00 & 3.8747 & 3.4053 & .11372 & .56862 & 3.6400 & 25 & بكالوريوس & \multirow{3}{*}{ حور التقويم } \\
\hline 4.00 & 1.00 & 4.3274 & 1.6726 & .51640 & 1.26491 & 3.0000 & 6 & دبلوم عالي & \\
\hline 4.00 & 1.00 & 3.7982 & 3.2340 & .13812 & .76902 & 3.5161 & 31 & المجموع & \\
\hline
\end{tabular}

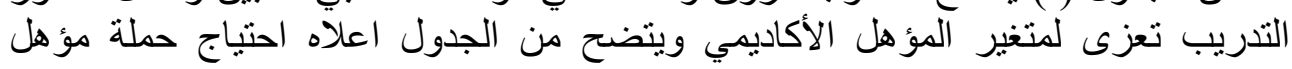

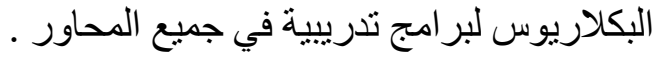


جدول رقم (IV) (IV): يوضح الفروقات ذات الدلالة الإحصائية بواسطة اختبار التباين بين عبارات محاور التدريب والمؤهل الأكاديمي لمعلمات صعوبات الإن التعلم (ANOVA)

\begin{tabular}{|c|c|c|c|c|c|c|}
\hline \multicolumn{7}{|c|}{ اختبار التباين (ANOVA) } \\
\hline |القيمة الاحتمالية & القيمة (ف) & الحسبع الوسي & الدرجة & المجموع من & \multicolumn{2}{|c|}{ المحاور } \\
\hline \multirow[t]{3}{*}{.203} & 1.696 & 723 & 1 & .723 & بين المجمو عات & \multirow{3}{*}{ المعارف } \\
\hline & & 427 & 29 & 12.373 & مع المجمو عات & \\
\hline & & & 30 & 13.097 & المجموع & \\
\hline \multirow[t]{3}{*}{.119} & 2.582 & .881 & 1 & .881 & بين المجمو عات & \multirow{3}{*}{ المهارات } \\
\hline & & .341 & 29 & 9.893 & مع المجمو عات & \\
\hline & & & 30 & 10.774 & المجموع & \\
\hline \multirow[t]{3}{*}{652} & 207 & .042 & 1 & .042 & بين المجمو عات & \multirow{3}{*}{ لاحتياجات } \\
\hline & & .203 & 29 & 5.893 & مع المجمو عات & \\
\hline & & & 30 & 5.935 & المجموع & \\
\hline \multirow[t]{3}{*}{.066} & 3.647 & 1.982 & 1 & 1.982 & بين المجمو عات & \multirow{3}{*}{ التقويم } \\
\hline & & .543 & 29 & 15.760 & مع المجمو عات & \\
\hline & & & 30 & 17.742 & المجموع & \\
\hline
\end{tabular}

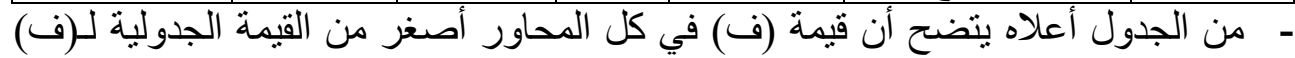

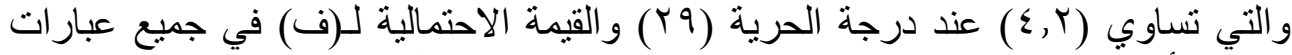

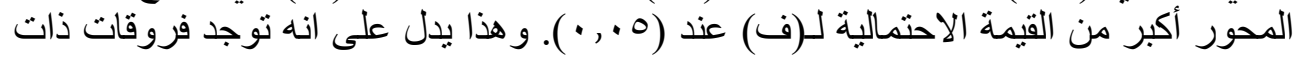

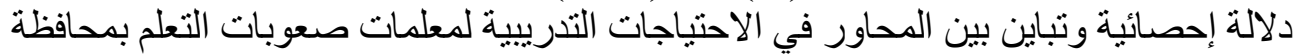
و وادي الدواسر تعزى لمتغير المؤهل الأكاديمي.

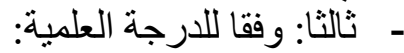




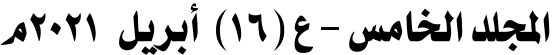

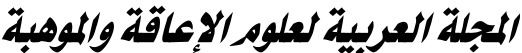

جدول رقم (^) (1): يوضح الفروقات في الوسط الحسابي بين عبار ات محاور التدريب و الدرجة العلمية لمعلمات صعوبات التعلم بمحافظة وادي الدوات السر :

\begin{tabular}{|c|c|c|c|c|c|c|c|c|c|}
\hline \multicolumn{10}{|c|}{ المتو سطات الحسابية } \\
\hline \multirow[t]{2}{*}{ الأعلى } & \multirow[t]{2}{*}{ الأننى } & \multicolumn{2}{|c|}{ محسوب التقة عند نسبة 90\% الحسبي } & \multirow{2}{*}{ المعياري } & \multirow{2}{*}{ الانحراف } & \multirow{2}{*}{ الحسابي } & \multirow[t]{2}{*}{ العدد } & \multirow{2}{*}{\multicolumn{2}{|c|}{ المحاور }} \\
\hline & & أعلى وزن & أقل وزن & & & & & & \\
\hline 4.00 & 2.00 & 4.2524 & 3.3476 & .20000 & .63246 & 3.8000 & 10 & أخرى & \\
\hline 4.00 & 2.00 & 3.9502 & 3.2498 & .16330 & .63246 & 3.6000 & 15 & تربية عامة & \\
\hline 4.00 & 2.00 & 6.2018 & .4649 & 66667 & 1.15470 & 3.3333 & 3 & تربية أساس & \\
\hline 4.00 & 3.00 & 5.1009 & 2.2324 & .33333 & .57735 & 3.6667 & 3 & تربية خاصة & \\
\hline 4.00 & 2.00 & 3.8875 & 3.4028 & .11867 & .66073 & 3.6452 & 31 & المجموع & \\
\hline 4.00 & 3.00 & 4.1262 & 3.6738 & .10000 & .31623 & 3.9000 & 10 & أخرى & \\
\hline 4.00 & 2.00 & 3.9502 & 3.2498 & .16330 & .63246 & 3.6000 & 15 & تربية عامة & \\
\hline 4.00 & 2.00 & 6.2018 & .4649 & .66667 & 1.15470 & 3.3333 & 3 & تربية أساس & \\
\hline 4.00 & 3.00 & 5.1009 & 2.2324 & .33333 & .57735 & 3.6667 & 3 & تربية خاصة & \\
\hline 4.00 & 2.00 & 3.8972 & 3.4576 & .10763 & .59928 & 3.6774 & 31 & الدجموع & \\
\hline 4.00 & 3.00 & 4.1262 & 3.6738 & .10000 & .31623 & 3.9000 & 10 & أخرى & \\
\hline 4.00 & 3.00 & 3.8808 & 3.3192 & .13093 & .50709 & 3.6000 & 15 & تربية عامة & مـ \\
\hline 4.00 & 3.00 & 5.1009 & 2.2324 & .33333 & .57735 & 3.6667 & 3 & تربية أساس & الاحتياجا \\
\hline 4.00 & 4.00 & 4.0000 & 4.0000 & .00000 & .00000 & 4.0000 & 3 & تربية خاصة & التدريبية \\
\hline 4.00 & 3.00 & 3.9051 & 3.5788 & .07989 & .44480 & 3.7419 & 31 & المجموع & \\
\hline 4.00 & 3.00 & 4.1016 & 3.4984 & .13333 & .42164 & 3.8000 & 10 & أخرى & \\
\hline 4.00 & 1.00 & 3.9951 & 3.0716 & .21529 & .83381 & 3.5333 & 15 & تربية عامة & \\
\hline 4.00 & 2.00 & 5.4841 & .5159 & .57735 & 1.00000 & 3.0000 & 3 & تربية أساس & مخت \\
\hline 4.00 & 2.00 & 5.4841 & .5159 & .57735 & 1.00000 & 3.0000 & 3 & تربية خاصة & \\
\hline 4.00 & 1.00 & 3.7982 & 3.2340 & .13812 & .76902 & 3.5161 & 31 & المجموع & \\
\hline
\end{tabular}

- من الجدول أعلاه يتضح أنه توجد فروق واضحة في الوسط الحسابي ما بين وداخل

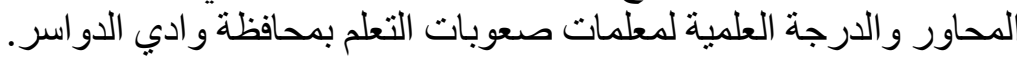

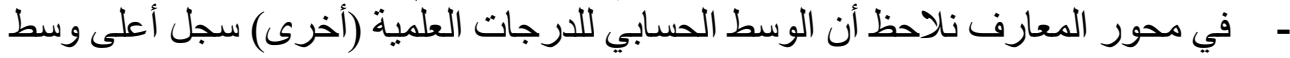

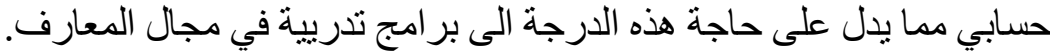

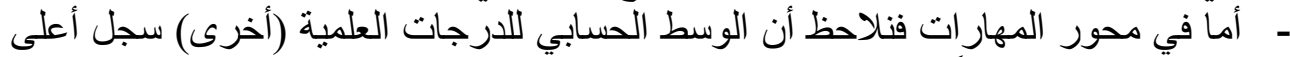

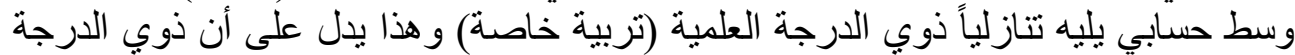

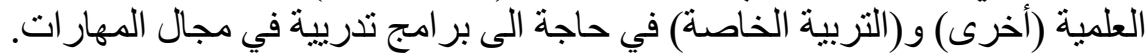


- جدول رقم (9) (19): يوضح الفروقات ذات الدلالة الإحصائية بواسطة اختبار التباين (ANOVA)

\begin{tabular}{|c|c|c|c|c|c|c|}
\hline \multicolumn{7}{|c|}{ اختبار الثباين (ANOVA) } \\
\hline \multirow{3}{*}{ 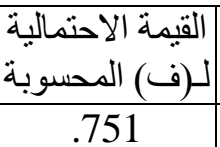 } & \multirow{3}{*}{ الثحسوبة } & \multirow{3}{*}{ الحسابي } & \multirow{2}{*}{ الحرجية } & \multirow{3}{*}{ المجموع من } & \multirow{2}{*}{\multicolumn{2}{|c|}{ المحاور }} \\
\hline & & & & & & \\
\hline & & & 3 & & بين المجمو عات & \\
\hline & & 464 & 27 & 12.533 & مع المجمو عات & \\
\hline & & & 30 & 13.097 & 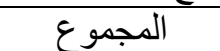 & \\
\hline 473 & .861 & 314 & 3 & 941 & بين المجمو عات & \\
\hline & & 364 & 27 & 9.833 & مع المجمو عات & هو \\
\hline & & & 30 & 10.774 & 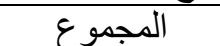 & \\
\hline 282 & 1.339 & 256 & 3 & 769 & بين المجمو عات & \\
\hline & & 191 & 27 & 5.167 & مع المجمو عات & الاحتياجات \\
\hline & & & 30 & 5.935 & 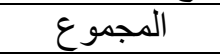 & 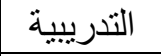 \\
\hline 260 & 1.414 & 803 & 3 & 2.409 & بين المجمو عات & \\
\hline & & 568 & 27 & 15.333 & مع المجمو عات & محتور \\
\hline & & & 30 & 17.742 & 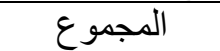 & \\
\hline
\end{tabular}

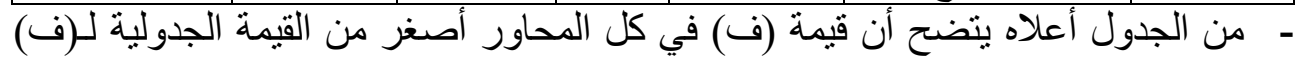

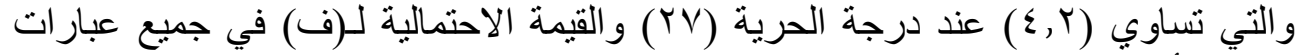

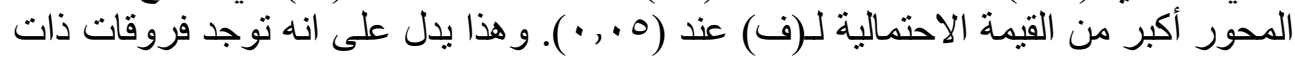

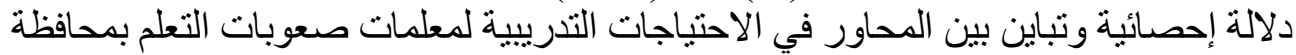
وادي الدواسر تعزى لمتغير الدرجة العلمية. - - مابعا:الفروق وفقال لعدد سنوات الخبرة: 
جدول رقم (• r): يوضح الفروقات في الوسط الحسابي بين عبار ات محاور التنريب و عدد

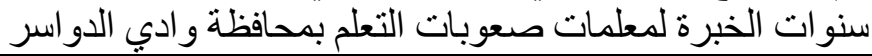

\begin{tabular}{|c|c|c|c|c|c|c|c|c|c|}
\hline \multicolumn{10}{|c|}{ الصنوسطات الحسابية } \\
\hline \multirow[t]{2}{*}{ لأعلى } & & سوب مند نسبة & 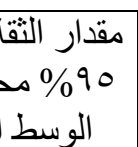 & & & الإسابيط & & \multicolumn{2}{|c|}{ الدحاور } \\
\hline & & أعلى وزن & أقلَ وزن & & & & & & \\
\hline 1.00 & 00 & 4.0060 & 3.6236 & 302 & .48334 & 3.8148 & 27 & لـ إت فأقل & \\
\hline 3.00 & 2.00 & 3.4187 & 1.5813 & 3868 & .57735 & 2.5000 & 4 & 10 - 6سنو ات & \\
\hline 00 & 2.00 & 3.8875 & 3.4028 & 1867 & .66073 & 3.6452 & 31 & المجموع & \\
\hline .00 & 3.00 & 3.9951 & 3.7086 & 6967 & .36201 & 3.8519 & 27 & كـ سنو ات فأقلّل & \\
\hline 3.00 & 2.00 & 3.4187 & 1.5813 & 8868 & .57735 & 2.5000 & 4 & 10 - 6 سنو ات & \\
\hline 4.00 & 2.00 & 3.8972 & 3.4576 & 0763 & .59928 & 3.6774 & 31 & المجموع & \\
\hline 4.00 & 3.00 & 3.9 & 3.6582 & 7618 & .39585 & 3.8148 & 27 & 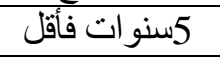 & \\
\hline 00 & & & 4 & 5000 & 00 & 500 & 4 & 6 سنوات & \\
\hline 4.00 & 3.00 & 3. & 3.5788 & 7989 & .44480 & 3.7419 & 31 & المجموع & - \\
\hline 4.00 & 3.00 & 3.9174 & 3.5641 & .08594 & .44658 & 3.7407 & 27 & 5 سنو ات فأقلّل & \\
\hline 3.00 & .00 & & .7008 & 40825 & & 2.00 & 4 & 1 - 6 سنوات & \\
\hline 1.00 & 00 & 82 & 3.2340 & .13812 & .76902 & 3.5161 & & المجموع & \\
\hline
\end{tabular}

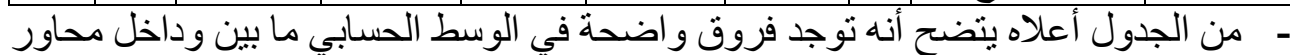

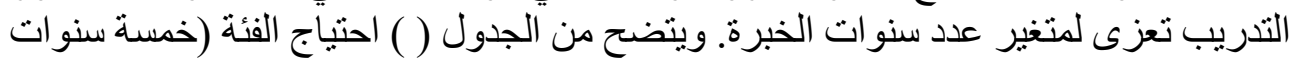
فاقل الى برامج تدريية في جميع الالمحاور جدول رقم ( (Y): يوضح الفروقات ذات الدالة الإحصائية بين عبار ات محاور التدريب و عدد

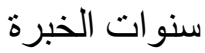

\begin{tabular}{|c|c|c|c|c|c|c|}
\hline \multicolumn{7}{|c|}{ اختبار التباين (ANOVA) } \\
\hline |القيمة الاحتمالية & قيمة (ف) & بربع الوسط & درجة & المجموع من & \multirow{2}{*}{\multicolumn{2}{|c|}{ الححاور }} \\
\hline |لـإن) الدحسوبة & المحسوبة & الحسابي & الحرية & المربعات & & \\
\hline \multirow[t]{3}{*}{.000} & 24.690 & 6.023 & 1 & 6.023 & بين المجمو عات & \multirow{3}{*}{ المعارف } \\
\hline & & 244 & 29 & 7.074 & مع المجمو عات & \\
\hline & & & 30 & 13.097 & 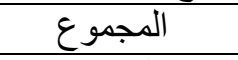 & \\
\hline \multirow[t]{3}{*}{.000} & 41.892 & 6.367 & 1 & 6.367 & بين المجمو عات & \multirow{3}{*}{ الدهارات } \\
\hline & & 152 & 29 & 4.407 & مع المجمو عات & \\
\hline & & & 30 & 10.774 & 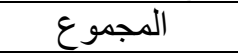 & \\
\hline .015 & 6.681 & 1.111 & 1 & 1.111 & بين المجمو عات & محور \\
\hline
\end{tabular}


Doi: 10.21608/jasht.2021.161836

هنادي/إبراهيه - د.سهر ميرغني

\begin{tabular}{|c|c|c|c|c|c|c|}
\hline & & .166 & 29 & 4.824 & مع المجمو عات & الاحتياجات \\
\hline & & & 30 & 5.935 & المجموع & التدرييية \\
\hline \multirow{3}{*}{.000} & 42.608 & 10.557 & 1 & 10.557 & بين المجمو عات & \multirow{3}{*}{ التقويم } \\
\hline & & .248 & 29 & 7.185 & مع المجمو عات & \\
\hline & & & 30 & 17.742 & المجموع & \\
\hline
\end{tabular}

من الجدول أعلاه يتضح أن قيمة (ف) في كل المحاور أصغر من القيمة الجدولية لــ(ف) و التي التي

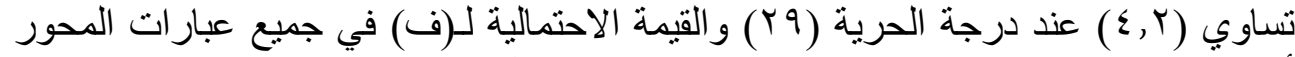

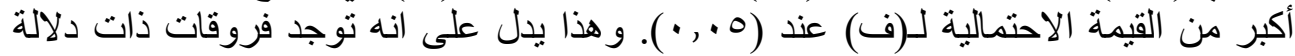
إحصائية وتباين بين المحاور في الاحتياجات التدريية لمتية لمعلمات صعوبات التيات التعلم بمحافظة

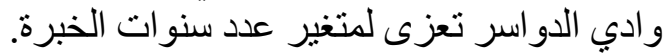

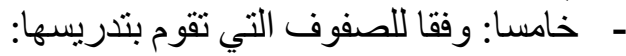
جدول رقم (Yr): يوضح الفروقات في الوسط الحسابي بين عبار ات محاور التدريب لمعلمات

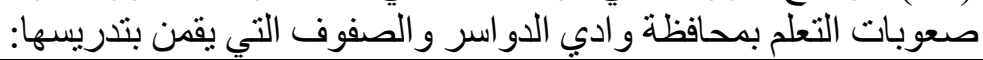

\begin{tabular}{|c|c|c|c|c|c|c|c|c|c|}
\hline \multicolumn{10}{|c|}{ المتوسطات الحسابية } \\
\hline \multirow{3}{*}{ |الأعلى } & \multirow{3}{*}{\begin{tabular}{|l} 
الأدنى \\
2.00
\end{tabular}} & \multicolumn{2}{|c|}{ 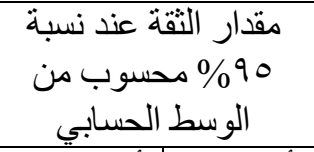 } & \multirow[t]{2}{*}{ | المعياري } & \multirow[t]{2}{*}{ الانحياري } & \multirow[t]{2}{*}{ دا |لحسابي } & العدد & \multirow{2}{*}{\multicolumn{2}{|c|}{ المحاور }} \\
\hline & & أعلى وزن & أقلّ وزن & & & & & & \\
\hline & & 4.0080 & 3.1920 & .19024 & .73679 & 3.6000 & 15 & أول ـ ثاني - ثالث & \\
\hline 4.00 & 3.00 & 4.1016 & 3.4984 & .13333 & .42164 & 3.8000 & 10 & رابع - خامس - & المعارف \\
\hline 4.00 & 2.00 & 4.3780 & 2.6220 & .34157 & .83666 & 3.5000 & 6 & سابع -ثامن & \\
\hline 4.00 & 2.00 & 3.8875 & 3.4028 & .11867 & .66073 & 3.6452 & 31 & المجموع & \\
\hline 4.00 & 2.00 & 4.0085 & 3.3249 & .15936 & .61721 & 3.6667 & 15 & أول ـ ثالثي - ثانث & \\
\hline 4.00 & 3.00 & 4.1016 & 3.4984 & .13333 & .42164 & 3.8000 & 10 & رابع - خامس - & المهار ات \\
\hline 4.00 & 2.00 & 4.3780 & 2.6220 & .34157 & .83666 & 3.5000 & 6 & سابع - ثامن & \\
\hline 4.00 & 2.00 & 3.8972 & 3.4576 & .10763 & .59928 & 3.6774 & 31 & المجموع & \\
\hline 4.00 & 3.00 & 3.9369 & 3.3964 & .12599 & .48795 & 3.6667 & 15 & أول ـ ثالثي - ثانث & محور. \\
\hline 4.00 & 3.00 & 4.1262 & 3.6738 & .10000 & .31623 & 3.9000 & 10 & |رابع - خامس - & الاحتياجية \\
\hline
\end{tabular}




\begin{tabular}{|c|c|c|c|c|c|c|c|c|c|}
\hline 4.00 & 3.00 & 4.2086 & 3.1247 & .21082 & .51640 & 3.6667 & 6 & سابع - ثامن & \\
\hline 4.00 & 3.00 & 3.9051 & 3.5788 & .07989 & .44480 & 3.7419 & 31 & المجموع & \\
\hline 4.00 & 2.00 & 3.9502 & 3.2498 & .16330 & .63246 & 000 & 15 & أول ـ ثاني - & \multirow{4}{*}{ التقويم } \\
\hline 0 & 2.00 & 4.0 & 2.9942 & .22361 & .70711 & 5000 & 10 & |رابع - خامس - & \\
\hline 4.00 & 1.00 & 4.6043 & 2.0624 & .49441 & 1.211 & 3.3333 & 6 & سابع - ثامن & \\
\hline 00 & 1.00 & 3.7982 & 3.2340 & 13812 & .76902 & .5161 & 31 & المجموع & \\
\hline
\end{tabular}

- من الجدول أعلاه يتضح أنه توجد فروقات في الوسط الحسابي بين وداخل جميع المحاور

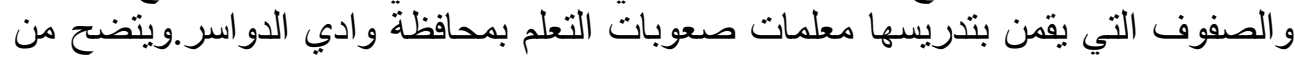

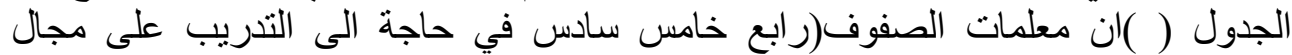

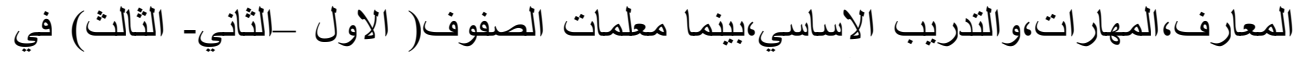
حاجة الى بر امج تدريبية في مجال التقويم.

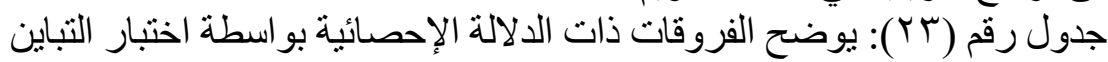

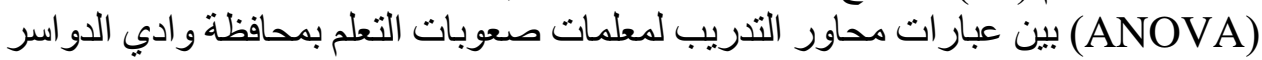
و الصفوف التي يقمن بتدريسها:

\begin{tabular}{|c|c|c|c|c|c|c|}
\hline \multicolumn{7}{|c|}{ اختبار التباين (ANOVA) } \\
\hline | القيمة الاحتمالية & قيمة (ف) & ربع الوسط & | درجة & المجموع من & \multirow{2}{*}{\multicolumn{2}{|c|}{ المحاور }} \\
\hline لـلـف) المحسوبة & المحسوبة & الحسابي & 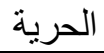 & المربعات & & \\
\hline \multirow{3}{*}{.650} & \multirow{3}{*}{.437} & .198 & 2 & .397 & بين المجمو عات & \multirow{3}{*}{ محور المعارف } \\
\hline & & .454 & 28 & 12.700 & مع المجموعات & \\
\hline & & & 30 & 13.097 & المجموع & \\
\hline \multirow{3}{*}{.638} & \multirow{3}{*}{.457 } & .170 & 2 & .341 & بين المجمو عات & \multirow{3}{*}{ محور المهارات } \\
\hline & & .373 & 28 & 10.433 & مع المجمو عات & \\
\hline & & & 30 & 10.774 & المجمو ع & \\
\hline \multirow{3}{*}{.407} & \multirow{3}{*}{.928} & .184 & 2 & .369 & بين المجمو عات & \multirow{3}{*}{ الاحنياجات } \\
\hline & & .199 & 28 & 5.567 & مع المجمو عات & \\
\hline & & & 30 & 5.935 & المجموع & \\
\hline \multirow{3}{*}{.782} & \multirow{3}{*}{.248} & .154 & 2 & .309 & بين المجمو عات & \multirow{3}{*}{ محور التقويم } \\
\hline & & .623 & 28 & 17.433 & مع المجمو عات & \\
\hline & & & 30 & 17.742 & المجموع & \\
\hline
\end{tabular}

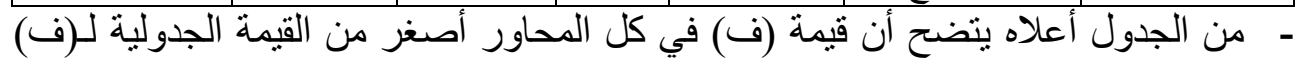

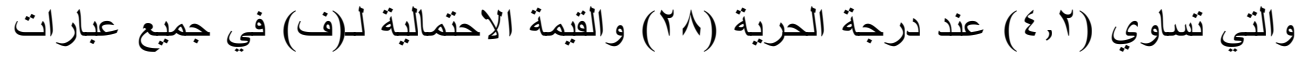




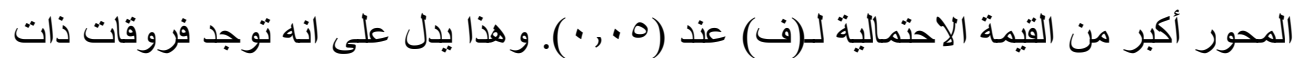

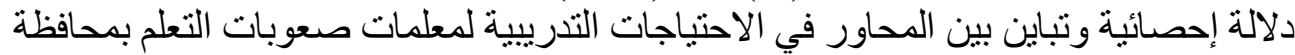
وادي الدواسر تعزى لمتغير الصفوف التي تقو التوم بتدريسها.

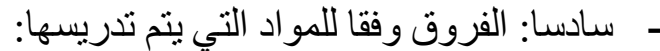
جدول رقم (ع Y): يوضح الفروقات في الوسط الحسابي بين عبار ات محاور التدريب لمعلمات

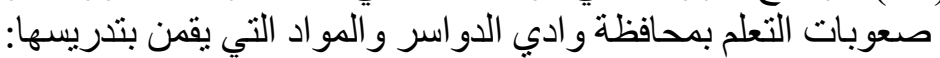

\begin{tabular}{|c|c|c|c|c|c|c|c|c|c|}
\hline \multicolumn{10}{|c|}{ المتوسطات الحسابية } \\
\hline \multirow{3}{*}{ لأعلى } & \multirow{3}{*}{ الأدنى| } & \multicolumn{2}{|c|}{ مقدار الثقة عند نسبة من الوسبة } & \multirow{3}{*}{ المعياري| } & \multirow{3}{*}{ الانحيراف افياري } & \multirow{3}{*}{\begin{tabular}{|l} 
الحسابي \\
\end{tabular}} & \multirow{3}{*}{\begin{tabular}{|l|} 
\\
16 \\
16 \\
\end{tabular}} & \multirow{2}{*}{\multicolumn{2}{|c|}{ المحاور }} \\
\hline & & أعلى وزن & أقلّل وزن & & & & & & \\
\hline & & 4.0570 & 3.6930 & & & & & لغة عربية & \\
\hline 4.00 & 2.00 & 3.8574 & 2.5426 & .29059 & .91894 & 3.2000 & 10 & رياضيات & \\
\hline 4.00 & 3.00 & 4.3553 & 3.2447 & .20000 & .44721 & 3.8000 & 5 & أخرى & \\
\hline 4.00 & 2.00 & 3.8875 & 3.4028 & .11867 & .66073 & 3.6452 & 31 & المجموع & \\
\hline 4.00 & 3.00 & 4.0273 & 3.5977 & .10078 & .40311 & 3.8125 & 16 & لغة عربية & \\
\hline 4.00 & 2.00 & 4.0032 & 2.7968 & .26667 & .84327 & 3.4000 & 10 & رياضيات & \\
\hline 4.00 & 3.00 & 4.3553 & 3.2447 & 20000 & .44721 & 3.8000 & 5 & أخرى & \\
\hline 4.00 & 2.00 & 3.8972 & 3.4576 & .10763 & .59928 & 3.6774 & 31 & المجموع & \\
\hline 4.00 & 3.00 & 4.0570 & 3.6930 & .08539 & .34157 & 3.8750 & 16 & لغة عربية & \\
\hline 4.00 & 3.00 & 4.0456 & 3.3544 & .15275 & .48305 & 3.7000 & 10 & رياضيات & \\
\hline 4.00 & 3.00 & 4.0801 & 2.7199 & .24495 & .54772 & 3.4000 & 5 & أخرى & \\
\hline 4.00 & 3.00 & 3.9051 & 3.5788 & .07989 & .44480 & 3.7419 & 31 & المجموع & \\
\hline 4.00 & 3.00 & 3.8914 & 3.3586 & .12500 & .50000 & 3.6250 & 16 & لغة عربية & \\
\hline 4.00 & 1.00 & 4.0121 & 2.3879 & .35901 & 1.13529 & 3.2000 & 10 & رياضيات & 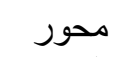 \\
\hline 4.00 & 3.00 & 4.3553 & 3.2447 & .20000 & .44721 & 3.8000 & 5 & أخرى & اللفويم \\
\hline 4.00 & 1.00 & 3.7982 & 3.2340 & .13812 & .76902 & 3.5161 & 31 & المجموع & \\
\hline
\end{tabular}
- من الجدول أعلاه يتضح أنه توجد فروق و اضحة في الوسط الحسابي ما بين وداخل محاور

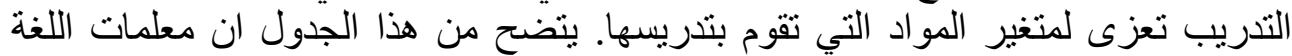

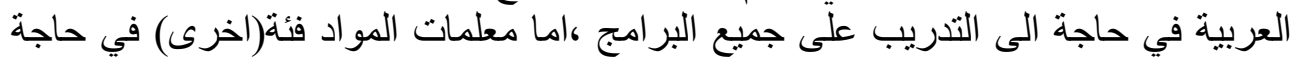

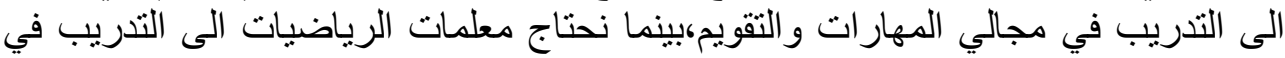
مجال الاحتياجات التدريبية الاساسية. 
جدول رقم (Y0) : يوضح الفروقات ذات الدلالة الإحصائية بو اسطة اختبار التباين

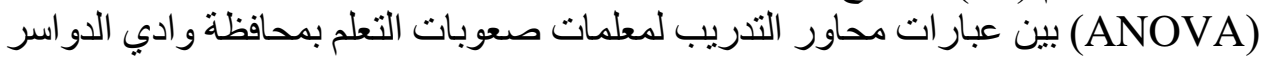
و المو اد التي يقمن بتدريسها:

\begin{tabular}{|c|c|c|c|c|c|c|}
\hline \multicolumn{7}{|c|}{ اختبار التباين (ANOVA) } \\
\hline القيمة الاحتمالية & قيمة (ف) & كربع الوسد & ل درجة & المجموع من & \multirow{2}{*}{\multicolumn{2}{|c|}{ المحاور }} \\
\hline للـ(ف) المحسوبة & المحسوبة & الحسابي & الحرية & المربعات & & \\
\hline .028 & 4.065 & 1.473 & 2 & 2.947 & بين المجمو عات & \multirow{3}{*}{ المعارف } \\
\hline & & .362 & 28 & 10.150 & مع المجموعات & \\
\hline & & & 30 & 13.097 & المجموع & \\
\hline \multirow[t]{3}{*}{.210} & 1.651 & .568 & 2 & 1.137 & بين المجمو عات & \multirow{3}{*}{ المهار ات } \\
\hline & & .344 & 28 & 9.638 & مع المجمو عات & \\
\hline & & & 30 & 10.774 & المجموع & \\
\hline \multirow[t]{3}{*}{.104} & 2.455 & .443 & 2 & .885 & بين المجمو عات & \multirow{3}{*}{ لاحتياجات } \\
\hline & & .180 & 28 & 5.050 & مع المجمو عات & \\
\hline & & & 30 & 5.935 & المجموع & \\
\hline \multirow[t]{3}{*}{.268} & 1.380 & .796 & 2 & 1.592 & بين المجمو عات & \multirow{3}{*}{ التقويم } \\
\hline & & .577 & 28 & 16.150 & مع المجمو عات & \\
\hline & & & 30 & 17.742 & المجموع & \\
\hline
\end{tabular}

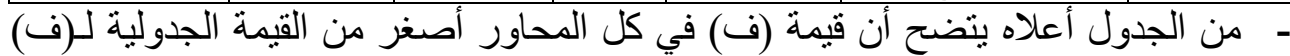

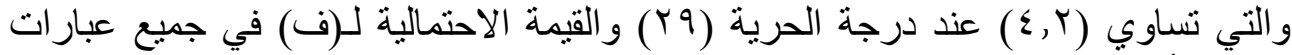

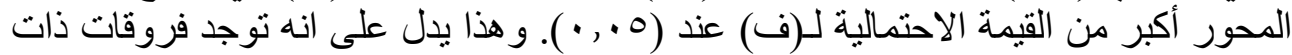

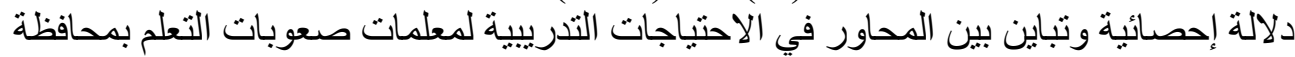
و ادي الدواسر تعزى لمتغير المو اد التي يقين التمن بتدريسها.

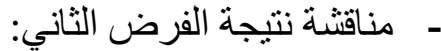

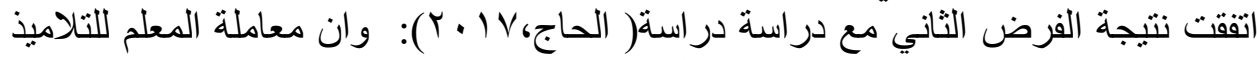

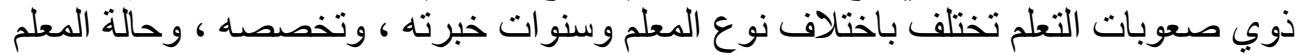

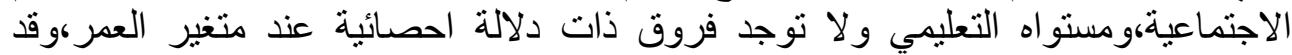

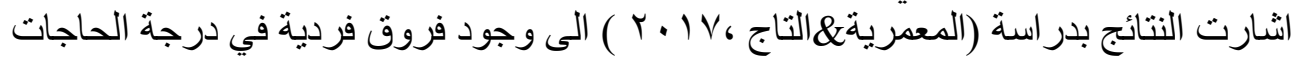

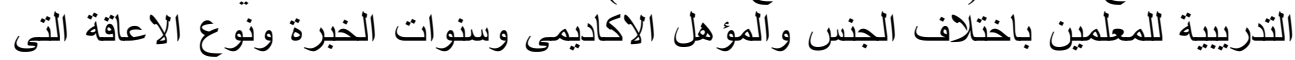

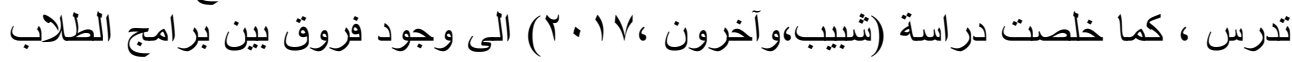

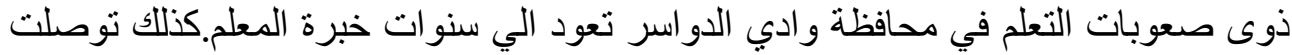

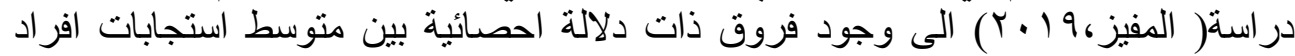

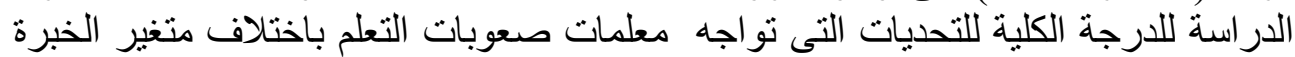


و الدورات التدريبية والمرحلة الدر اسية ونوع الصعوبة ووجود فروق ذات دلالة احصائية حول

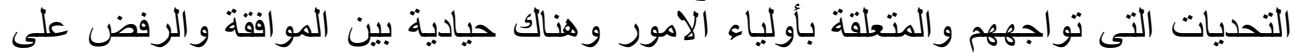

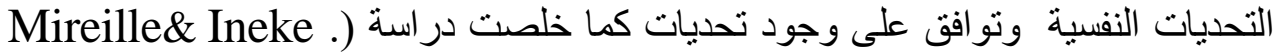

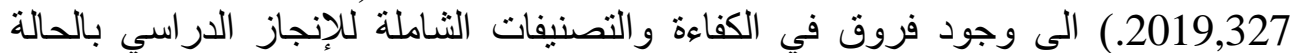
المهنية ونوع الصعوبات كذلك وجود تباين في تصنيفات المعلمين في الكفاءة الأكاديمية

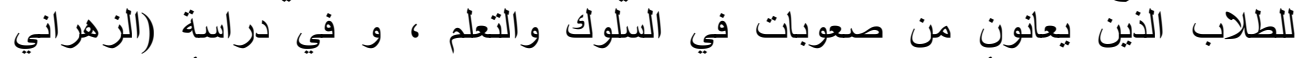

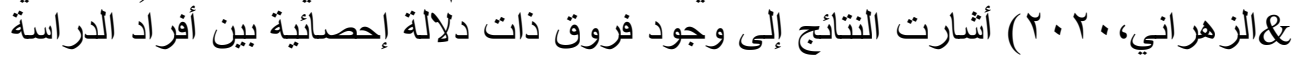

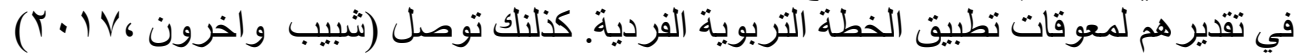

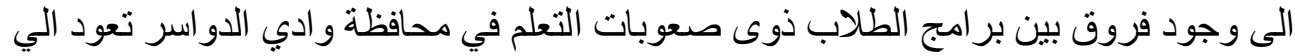
سنوات خبرة المعلم.

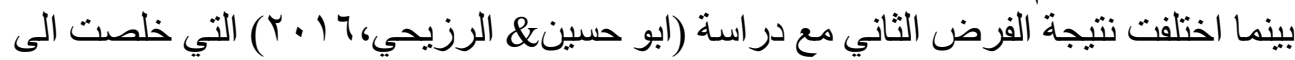

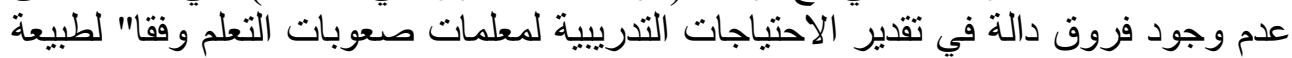

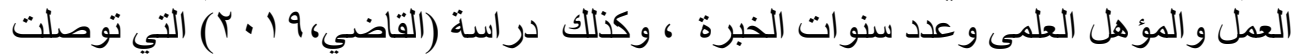

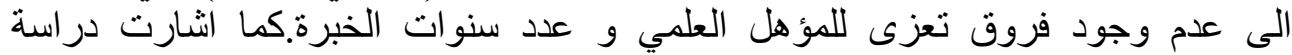

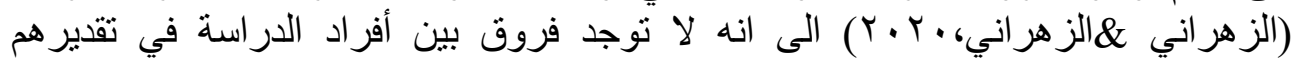

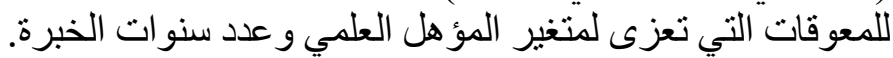

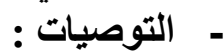

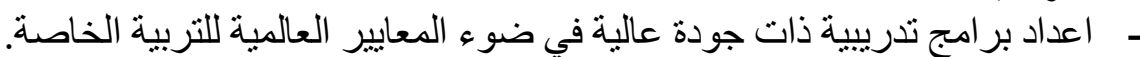

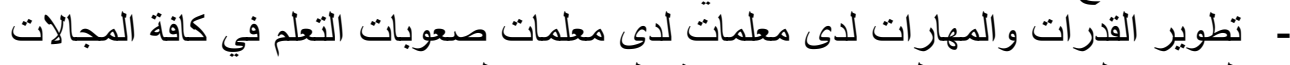

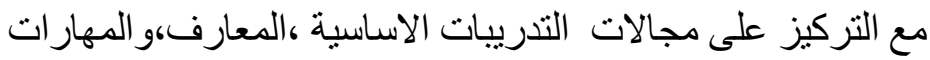

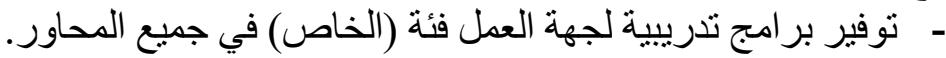

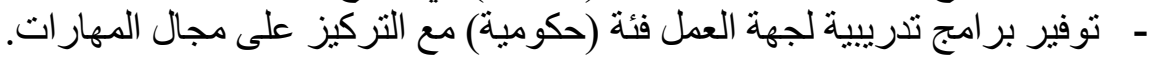

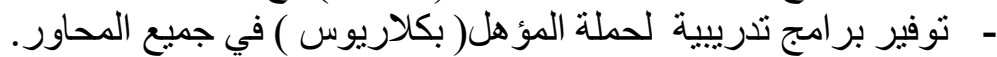

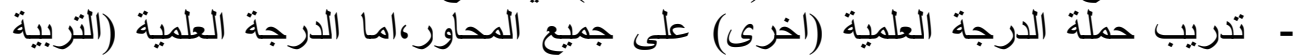

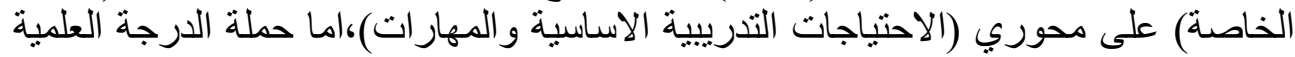
(تربية عامة) على محور التقويم.

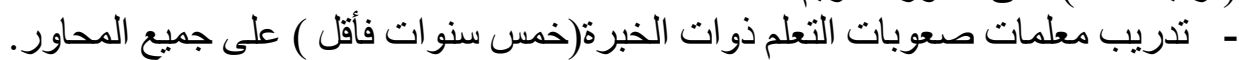

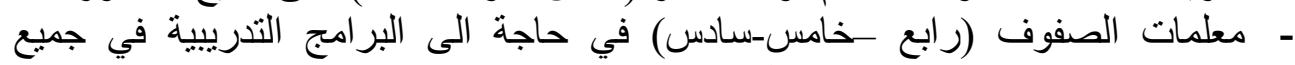

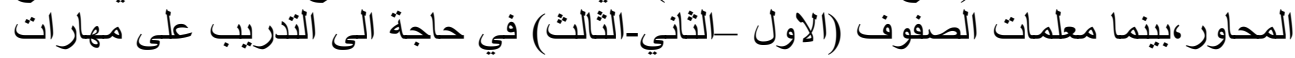
التقويم. 


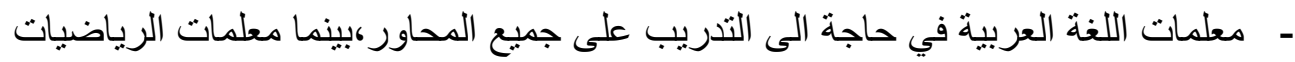

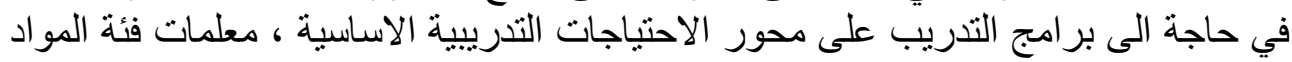
(اخرى) في حاجة الى التدريب فى مجالي التقويم و الاحتياجات التدريبية الاساسية. 


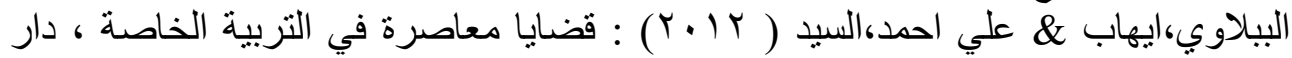

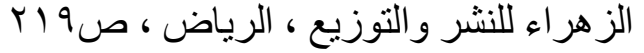

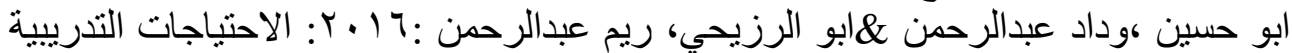

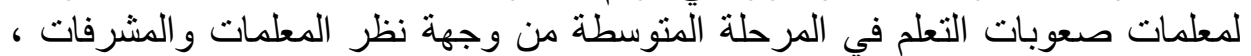

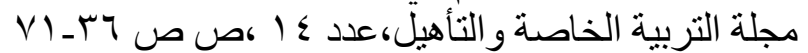

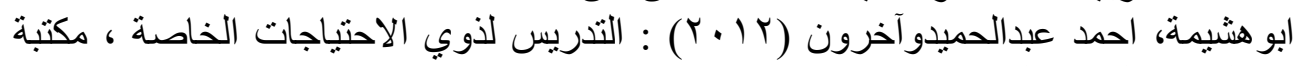

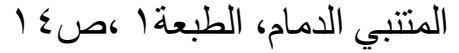

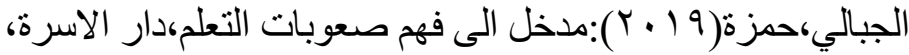

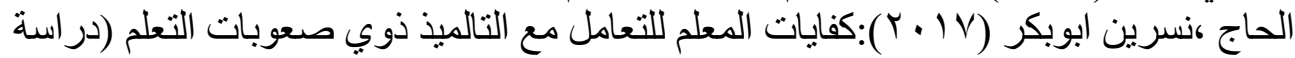

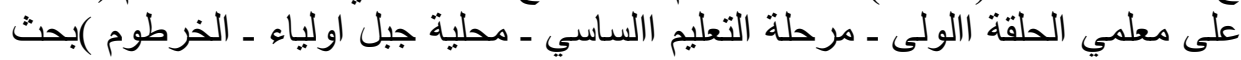

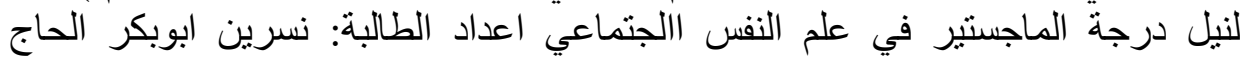

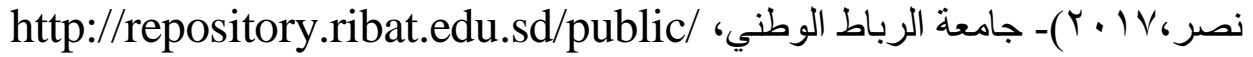

pdf

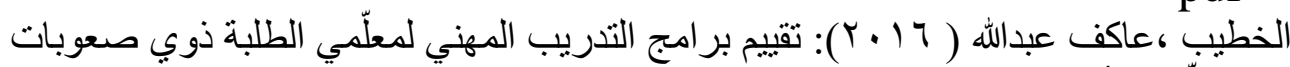

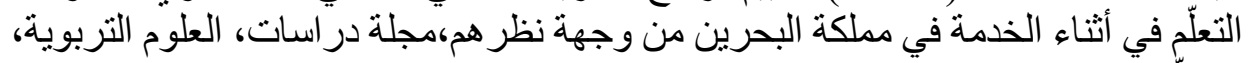

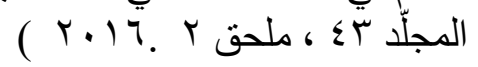

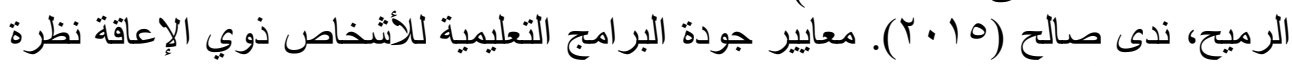

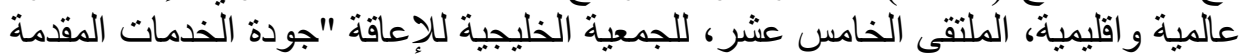

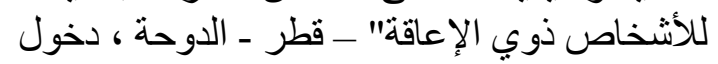
https://slpemad.files.wordpress.com/2016/

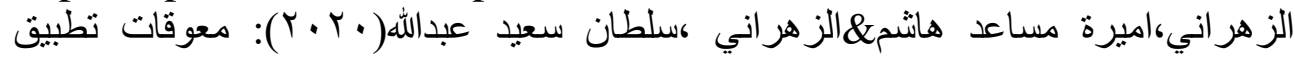

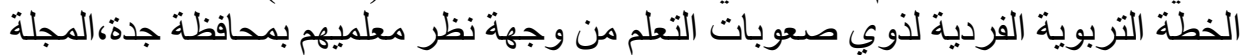

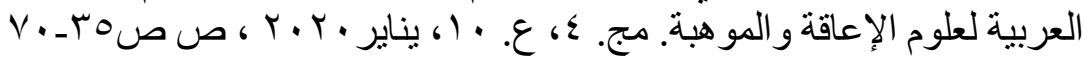

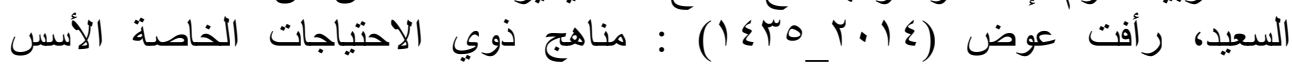

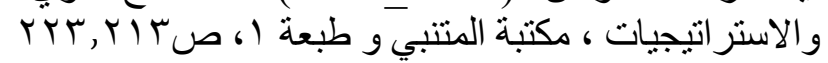

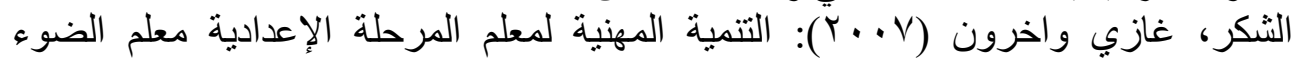

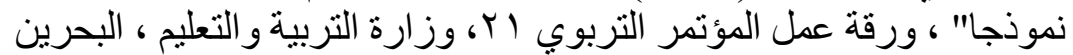

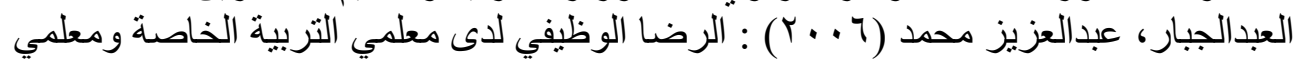

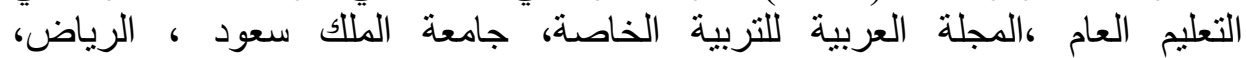
طبعة0،صو7 90 


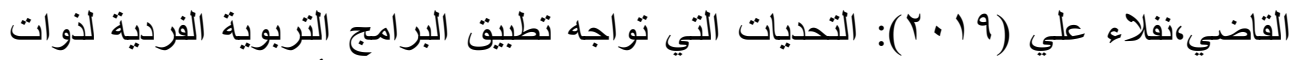

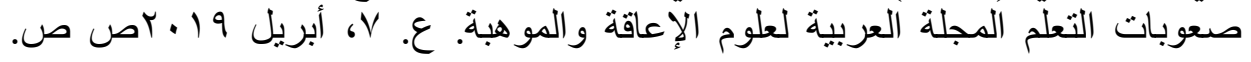

$$
\mid V \cdot-1 \leqslant 0
$$

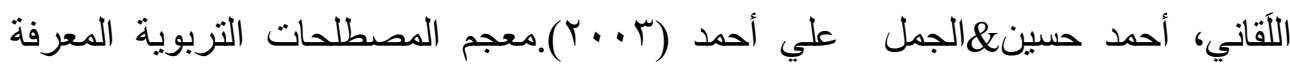

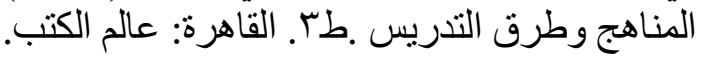

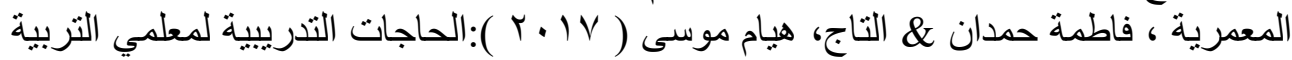

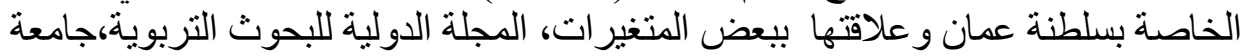

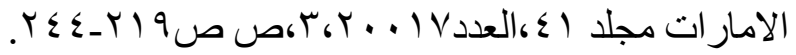

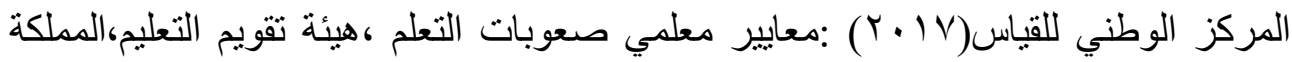

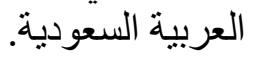

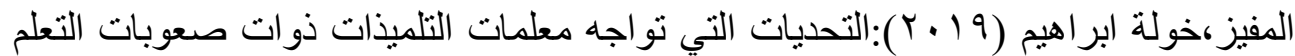

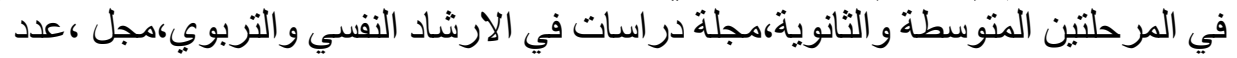

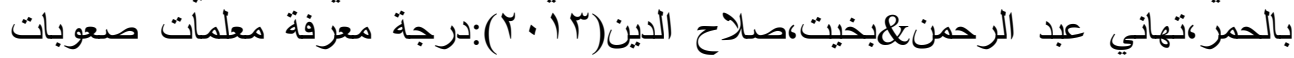

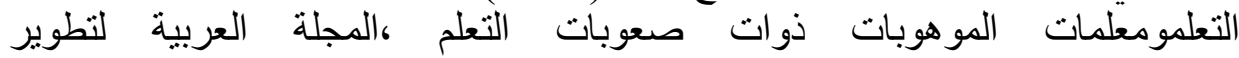

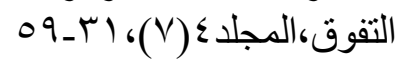

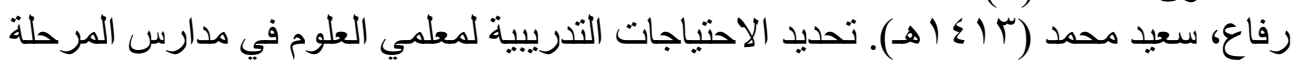

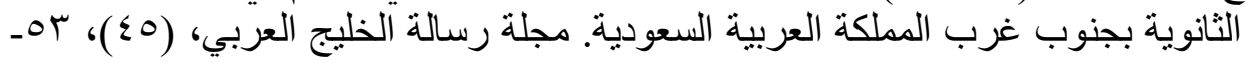

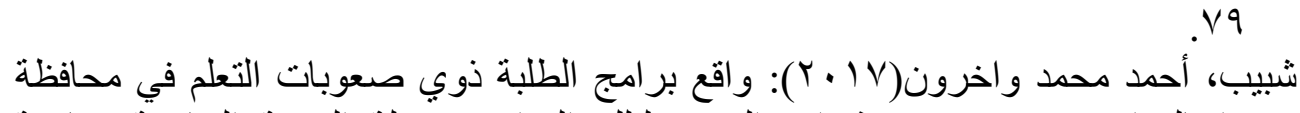

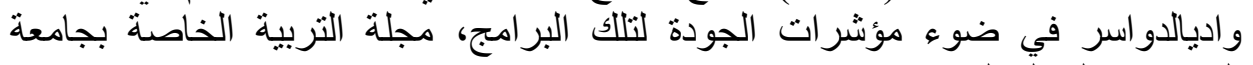

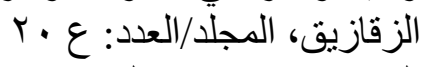

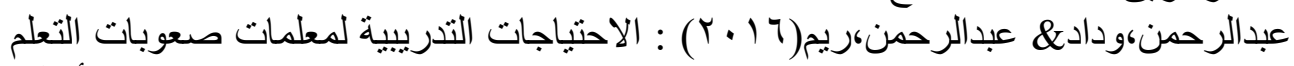

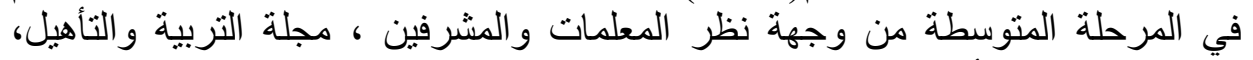

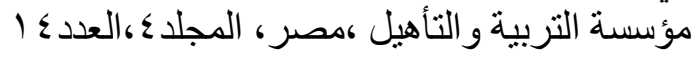

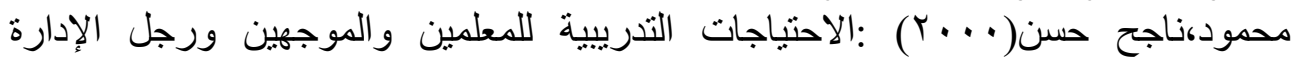

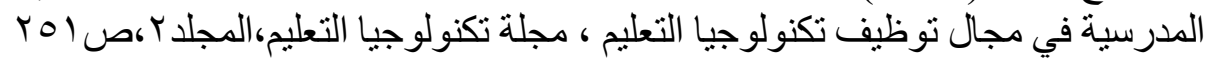

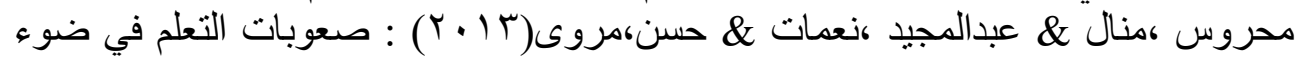

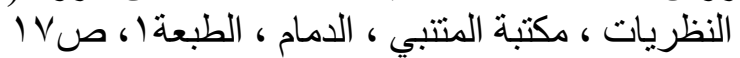

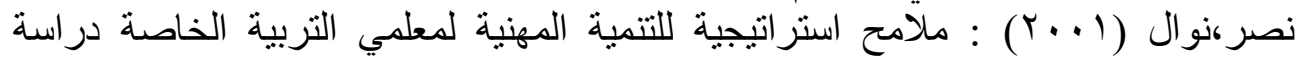

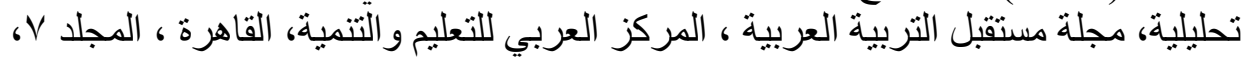
العدد بالبان 


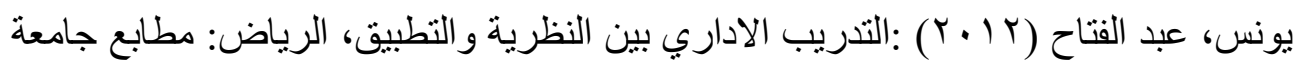
الملك سعود.

المراجع باللغة الانجليزية:

Brady, P(2013):Training needs of teachers difficulties ,Cambridge journal of education47,302-324

Mireille Krischler1,* and Ineke M. Pit-ten Cate2, $\uparrow$ Pre- and InService Teachers' Attitudes Toward Students With Learning Difficulties and Challenging Behavior, International Journal in Management and Social Science, February 2019, Front. Psychol., 25 February 2019 | https://doi.org/10.3389/fpsyg.2019.00327

Citro ,Teresa Allissa(2019): Learning Disabilities Worldwide https://www.ldworldwide.org/welcome?gclid=EAIaIQobChMI vcGG54yq5QIVQp3VCh1AXAIcEAAYASAAEgKZl_D_Bw

$\mathrm{E}$

Learning Disabilities Association of America (2019):Addressing the Needs of Students with Learning Disabilities, https://www.edu.gov.mb.ca/k12/docs/support/learn_disabilities/m odule2.pdf

Ahmad, N. A., \& May, Y. S. (2018). Challenges in Preparing Teachers for Inclusive Education and Its Impact to Students with Learning Disabilities. International Journal of Academic Research in Progressive Education and Development, 7(3), 569-581. 